\title{
First DO NO HARM: THE MANIPULATION OF PUBLIC HEALTH FOR NON-PUBLIC HEALTH PURPOSES AND ITS LEGAL CONSEQUENCES
}

\author{
Christopher OgOlla*
}

\section{INTRODUCTION}

The well-known aphorism "first do no harm" (primum non nocere), used in many medical schools today and attributed to the Hippocratic oath, serves as a guide to "doctors in caring for their patients." Although the oath has been described as individualistic, ${ }^{2}$ the aphorism holds equal if not a weightier value in public health practice. ${ }^{3}$ At its core, public health is concerned with promoting and protecting the health of populations. ${ }^{4}$ However, public health has often times been used to subvert the very same goals it is designed to achieve. This is what this Article refers to as using public health for non-public health purposes. The results can be, and often are, harmful to the practice.

This Article will focus on three examples to illuminate the risks of using public health for non-public health purposes; namely, the anti-abortion legislation, ${ }^{5}$ the 2014 Ebola virus disease outbreak, and the 2010 Patient

* Associate Professor of Law, Savannah Law School, 516 Drayton Street, Savannah, GA 31401. The author worked at the Centers for Disease Control and Prevention in Atlanta as an Association of Schools of Public Health (ASPH) research fellow. Additionally, he served as a public health representative for the New York State Department of Health, Division of TB Control, in New Rochelle, New York. This Article benefited greatly from the helpful suggestions and comments of Professor Darnell Weeden, Thurgood Marshall School of Law, Texas Southern University, who served as the main reviewer during the 2016 Southeast/Southwest People of Color Legal Scholarship Conference held February 25-28 in Orlando, Florida. I thank my colleague Professor Caprice Roberts, Savannah Law School for her precious comments and suggestions. Additionally, I wish to thank Robert Derrah, for his always insightful comments and critiques, Jill Kroamer for her outstanding research assistance, and Daniel Cordova for her helpful edits and verifying citations.

1. See D. R. Buchanan \& F. G. Miller, A Public Health Perspective on Research Ethics, 32 J. MeD. ETHICs 729, 729 (2006).

2. Id.

3. See generally Lawrence D. Brown, The Political Face of Public Health, 32 Pub. Health REVS. 155, 157 (2010) (noting "The first and foremost mission of public health is to protect the population against exposure to illnesses that are contagious person-to-person or transmissible from environmental sources ...”).

4. Ruth Faden \& Sirine Shebaya, Public Health Ethics, Stan. Encyclopedia Phil. (Apr. 12, 2010), http://plato.stanford.edu/entries/publichealth-ethics/ [https://perma.cc/Y28N-V6ZU].

5. Some may quibble with the term "anti-abortion legislation." To be fair, some of the statutes may encompass much more than restricting abortion. However, that does not take away from their primary purpose, which is an attempt to kill Roe v. Wade, 410 U.S. 113 (1973). In any case, this term has been used extensively by other authors. See Daniel Grossman et al., The Public Health Threat of Anti-Abortion Legislation, 89 CONTRACEPTION 73, 73-74 (2014); Michael New, 
Protection and Affordable Care Act. The discussion will attempt to answer the following specific questions. First, what are legitimate public health activities? Second, how has anti-abortion legislation, the 2014 Ebola virus disease outbreak, and the Affordable Care Act been used for non-public health purposes? Third, should these non-public health purposes warrant a more inhospitable reception within the public health community, in general, and courts, in specific? Finally, what should be plaintiffs' remedies?

Part I asserts that the aims of public health have often been compromised through political and legislative rhetoric resulting in tangible harm to the practitioners as well as the population served. Parts II and III provide general examples of manipulation of public health both within and outside the U.S. Part IV seeks to provide an answer to a difficult yet necessary question-what are legitimate public health activities?, arguing that this is a threshold question in order to determine whether public health is being used for non-public health purposes. Part V discusses the anti-abortion legislations, commonly referred to as Targeted Regulation of Abortion Providers (TRAP) laws, with specific focus on abortion restrictions in Texas and Wisconsin. It then discusses the U.S. Supreme Court's decision in Whole Woman's Health v. Hellerstedt, $136 \mathrm{~S}$. Ct. 2292 (2016), and its implications on public health practice. Parts VI and VII examine the manipulation of public health during the 2014 Ebola Virus Disease (EVD) outbreak and the 2010 Affordable Care Act legislation, respectively. Additionally, Part VII considers the Supreme Court's decision in Zubik v. Burwell, 136 S. Ct. 1557 (2016), reasoning that the Court has created a lot of uncertainty by not definitively rendering a decision in the challenge to the Affordable Care Act's contraceptive mandate. In Part VIII, this Article notes that manipulation of public health for non-public health purposes is actually an illegitimate use of public health; therefore, these actions should warrant a more inhospitable reception within the public health community in general and courts in particular. Against this backdrop, Part IX offers potential remedies for plaintiffs for harm suffered when public health is used for non-public health purposes. Finally, the Article concludes by reiterating to the reader that public health has often times been used to subvert the very same goals it is designed to achieve and that the results are often harmful to the practice. In addition to political recourse, it urges plaintiffs to seek remedies in courts, even though the reliefs may sometimes be limited.

\section{Manipulation of Public Health Activities Outside the U.S.}

In 2010 , the U.S. government revealed that it had conducted medical

Analyzing the Impact of U.S. Antiabortion Legislation in the Post-Casey Era, 14 ST. POL. \& PoL'Y Q. 228 (2014); Susan Weber, An Attempt to Legislate Morality: Forced Ultrasounds as the Newest Tactic in Anti-Abortion Legislation, 45 Tulsa L. Rev. 359 (2009); Erik Eckholm, Access to Abortion Falling as States Pass Restrictions, N.Y. TIMES (Jan. 3, 2014), http://www. nytimes.com/2014/01/04/us/women-losing-access-to-abortion-as-opponents-gain-ground-in-statelegislatures.html?_r=0 [https://perma.cc/49RB-KU52] ("Anti-abortion legislation in the states exploded after the major conservative gains in the 2010 elections."). 
experiments in the 1940s in which doctors infected soldiers, prisoners, and mental patients in Guatemala with syphilis and other sexually transmitted diseases. ${ }^{6}$ The Guatemalan study

involved at least 5,128 vulnerable people, including children, orphans, child and adult prostitutes, Guatemalan Indians, leprosy patients, mental patients, prisoners, and soldiers. Between 1946 and 1948, health officials intentionally infected at least 1,308 of these people with syphilis, gonorrhea, and chancroid and conducted serology tests on others. The study originally began in the United States but was moved to Guatemala when researchers were unable to consistently produce gonorrhea infections in prisoners at a Terre Haute, Indiana, prison. ${ }^{7}$

Then-Secretary of State Hilary Rodham Clinton, and Secretary of Health and Human Services Kathleen Sebelius, issued a joint apology stating that "[a]lthough these events occurred more than 64 years ago, we are outraged that such reprehensible research could have occurred under the guise of public health." ${ }^{8}$

In developing countries, particularly in Africa, the history of colonization indicates that Christian missionary groups, often with support from their governments, used public health and provision of medical services as a way of gaining converts and spreading the gospel. ${ }^{9}$ This marriage of public health and proselytization has now morphed into a field known as Community Health Evangelism. ${ }^{10}$

In 2011, the CIA admitted that it hired a Pakistani physician to set up a fictional vaccination program in Abbottabad, Pakistan, to purportedly administer

6. Rob Stein, U.S. Apologizes for Newly Revealed Syphilis Experiments Done in Guatemala, WASH. Post (Feb. 3, 2017, 3:00 PM), http://www.washingtonpost.com/wp-dyn/content/article/ 2010/10/01/AR2010100104457.html [https://perma.cc/BDE9-7UCK].

7. Michael Rodriguez \& Robert Garcia, First, Do No Harm: The US Sexually Transmitted Disease Experiments in Guatemala, 103 Am. J. Pub. Health 2122, 2122 (2013).

8. Stein, supra note 6.

9. See Ololade Olakanmi \& Philip A. Perry, Medical Volunteerism in Africa: An Historical Sketch, 8 Am. Med. Assoc. J. Ethics, 863, 863 (2006) ("There were about a dozen medical missionaries worldwide in 1850. In Africa, this was the time of David Livingstone, the Scottish explorer and missionary, and Cardinal Charles Lavigerie, a brilliant Catholic mission strategist . ... Even the earliest missionaries found that having the capability to meet the medical needs of indigenous populations opened up new towns and villages 'to the messengers of the gospel."').

10. See What Is CHE, CARTwright House (Feb. 15, 2015), http://cartwrightscfamily. blogspot.com/[https://perma.cc/8HY3-3YDW] ("Community Health Evangelism is a multifaceted approach to Christian ministry that addresses the needs of the whole person - physical, spiritual, emotional, and social."); see also Community Health Evangelism, CMF INT'L, http://www.cmfi. org/whatwedo/holisticdevelopment/che/ [https://perma.cc/NGK6-9L2K] (last visited Mar. 31, 2017) (“CHE often includes instruction on hygiene, clean water, safe cooking, latrines, health care, HIV/AIDS prevention and care and other basic life issues. CHE outreach programs are designed to reach non-Christians and are focused on evangelism, follow-up and discipleship.”). 
a polio vaccine. ${ }^{11}$ The goal was to obtain DNA samples from Osama bin Laden's compound. ${ }^{12}$ This resulted in a letter to the White House by some deans of schools of public health stating, in pertinent part that "as a general principle, public health programs should not be used as cover for covert operations." ${ }^{13}$ One may wonder why the deans of schools of public health would oppose using public health as a cover for finding and killing Osama bin Laden considering the evil, terror, and carnage perpetrated by Al-Qaeda. The inescapable conclusion is that the deans were likely concerned about the harm the program would cause to public health practice, including the poor optics of having intelligence operatives as public health workers. Epidemiologically, the injury of the fictional vaccination program is likely harm to those babies who are now not vaccinated because of mistrust of vaccination programs or the health workers whose lives are now at risk. For example, the letter observes that "[t]his past month, seven or more United Nations health workers who were vaccinating Pakistani children against polio were gunned down in unforgivable acts of terrorism."14

Concededly, (as of this writing) there is no epidemiological evidence showing that immunization rates have changed in Pakistan pre-and-post the killing of Osama bin Laden. ${ }^{15}$ However, on January 13, 2016, a suicide attack on a polio vaccination center killed sixteen people. ${ }^{16}$ This is attributable to the fact that

Polio workers in Pakistan, and their police escorts, have been targeted in recent years by Islamic militants who accuse them of working as spies

11. Donald G. McNeil, CIA Vaccine Ruse May Have Harmed the War on Polio, N.Y. Times (July 9, 2012), http://www.nytimes.com/2012/07/10/health/cia-vaccine-ruse-in-pakistan-may-haveharmed-polio-fight.html?pagewanted=all [https://perma.cc/R5QZ-KVBN].

12. Saeed Shah, CIA Organized Fake Vaccination Drive to Get Osama Bin Laden's Family DNA, GuARDiAn (July 11, 2011, 2:59 PM), http://www.theguardian.com/world/2011/jul/11/ciafake-vaccinations-osama-bin-ladens-dna [https://perma.cc/P6N3-9DTD].

13. See Deans' Letter to the White House, John Hopkins: Bloomberg Sch. of Pub. Health (Jan. 6, 2013), http://www.jhsph.edu/news/news-releases/2014/Deans_letter_to_WH_1413 finall.pdf [https://perma.cc/JV9Y-HR8E].

14. Id.

15. See generally Polio Eradication Initiative, WorLd HEALTH ORG., http://www.emro.who. int/polio/countries/pakistan.html [https://perma.cc/YRB6-ZETG] (last visited Mar. 31, 2017). The World Health Organization reports that

[a]lmost three million children miss out on a full course of the most basic vaccines every year in Pakistan, leaving them vulnerable to life-threatening diseases. Immunization coverage rates across the country vary widely with some districts seeing very few children protected against diseases, such as diphtheria, pertussis, tetanus, measles and bacterial pneumonia.

See Immunization Leaders Call for Increased Political Support for Immunization in Pakistan, World HeAlth ORG. (Feb. 19, 2015), http://www.emro.who.int/media/news/political-supportimmunization-pakistan.html [https://perma.cc/VU6R-2LAG].

16. Ihsanullah Tipu Mehsud, Suicide Bomb Near Polio Center in Pakistan Kills at Least 16, N.Y. TIMES (Jan. 13, 2016), https://www.nytimes.com/2016/01/14/world/asia/pakistan-quettasuicide-bombing-polio.html [https://perma.cc/CNR3-E22A]. 
for the United States. ... The attacks intensified after a Pakistani doctor was arrested on charges of running a fake hepatitis vaccination campaign in the city of Abbottabad as a cover for a CIA-backed effort to obtain DNA samples from Osama bin Laden ahead of the 2011 U.S. raid that killed him. ${ }^{17}$

The lesson here is that the manipulation of public health for national security reasons or to combat terrorism abroad should warrant a more inhospitable reception within the public health community. Regretfully, here in the U.S., examples of manipulation of public health for non- public health purposes are not merely a page of history but a whole volume.

\section{Manipulation of Public Health Activities in the U.S.}

In the U.S., there is a long history of governmental use of public health for non-public health purposes. For example, in the last years of the eighteenth century, "yellow fever epidemics fueled a political fracas between Republicans, who believed the disease had local origins, and Federalists, convinced it was imported by foreign enemies." 18 Party leaders adroitly exploited the medical controversy over yellow fever. The Federalist leaders used the importation theory to back demands for quarantine and exclusion of the French from the island of Saint-Domingue (modern day Haiti), whereas the Republican merchants saw importation as a pretext to wreck their lucrative trade with the Caribbean. ${ }^{19}$ As it turned out, the main aim of the Federalists was to arouse public suspicion of the French and radical Republicans in America. ${ }^{20}$ For the Federalists, quarantine was a weapon that could be used to discredit their opponents and forge a strong sense of national identity. ${ }^{21}$ Ironically, a similar situation played out during the 2014 Ebola disease outbreak. ${ }^{22}$ Only this time, it was the Republicans and Democrats blaming each other. ${ }^{23}$

In 1900, there were reported cases of the bubonic plague in Chinatown, San Francisco. ${ }^{24}$ As a result, the local board of health imposed complete quarantine of Chinatown. ${ }^{25}$ However, the quarantine order was enforced against persons of

17. Abdul Sattar, Suicide Attack on a Pakistan Polio Center Kills 15, Wash. Times (Jan. 13, 2016), http://www.washingtontimes.com/news/2016/jan/13/officials-bomb-attack-kills-14-inpakistan-polio-c/ [https://perma.cc/G85B-BDQG].

18. Brown, supra note 3, at 160.

19. Mark Harrison, Disease and the Modern World: 1500 to the Present Day 98-99 (2004)

20. $I d$.

21. Id.

22. See generally discussion of Ebola Virus Disease (EVD) infra Part IV.

23. HARRISON, supra note 19, at 99.

24. Robert Barde, Plague in San Francisco: An Essay Review, 59 J. Hist. Med. Allied Sci. 463, 464 (2004).

25. $I d$. 
the Chinese race and nationality only, and not against persons of other races. ${ }^{26}$ All stores, residences, and other buildings within the quarantined district occupied by persons of races other than Chinese were not subjected to any of the restrictions or limitations provided for by the quarantine order. ${ }^{27}$ Some commentators have observed that " $[\mathrm{t}] \mathrm{he}$ events that unfolded in San Francisco in 1899 to 1901 [during the plague] represent one of the most infamous chapters in U.S. public health history." 28 There, "[p]ublic health work failed when its campaign against plague racialized the disease and resulted in discriminatory public health activities." 29

In 1909, immunologist Paul Ehrlich announced the discovery of Salvarsan, a cure for syphilis. ${ }^{30}$ In 1943, John Mahoney of the U.S. Public Health Service found that a strain of penicillin was effective in treating syphilitic rabbits. ${ }^{31}$ This led to massive production of penicillin for treating syphilis. ${ }^{32}$ Yet between 1932 and 1972, the U.S. Public Health service conducted research in Tuskegee Alabama, where hundreds of African-American men were left untreated so as to study the effects of syphilis, despite the fact that there was a known cure. ${ }^{33}$ One commentator has noted that "[ $t]$ he ultimate tragedy of the Tuskegee experiment was exemplified by the extraordinary measures taken to ensure that subjects in the experimental group did not receive effective treatment." ${ }^{34}$

During WWI, Congress passed the Chamberlain-Kahn Act of $1918,{ }^{35}$ which established a civilian quarantine and isolation fund, as part of a comprehensive venereal disease program. ${ }^{36}$ It gave the government the power to quarantine any woman suspected of having a sexually transmitted disease. ${ }^{37}$ The purpose of this law was to prevent the spread of venereal diseases among U.S. soldiers because it was "feared that soldiers in training would visit prostitutes, become infected,

26. See generally id.

27. Jew Ho v. Williamson, 103 F. 10, 12 (C.C.N.D. Cal. 1900).

28. David M. Morens \& Anthony S. Fauci, The Forgotten Forefather: Joseph James Kinyoun and the Founding of the National Institutes of Health, 3 MBIO 1, 4 (July-Aug. 2012), https://www.ncbi.nlm.nih.gov/pmc/articles/PMC3388889/ [https://perma.cc/TPF8-UKR8].

29. See Judith Walzer Leavitt, 'The Barbary Plague': When the Black Death Stalked San Francisco, N.Y. Times (Apr. 27, 2003), http:/www.nytimes.com/2003/04/27/books/review/ 27LEAVITT.html [https://perma.cc/BJS3-UGEE].

30. Allan M. Brandt, The Syphilis Epidemic and Its Relation to AIDS, 239 ScI. 375, 375 (1988).

31. Id. at 379 .

32. Id.

33. Stein, supra note 6 .

34. Stephen B. Thomas \& Sandra Crouse Quinn, Public Health Then and Now: The Tuskegee Syphilis Study, 1932 to 1972: Implications for HIV Education and AIDS Risk Education Programs in the Black Community, 81 Am. J. Pub. Health 1498, 1501 (1991).

35. Chamberlain-Kahn Act, Pub. L. No. 65-193, 40 Stat. 845 (1918).

36. Brandt, supra note 30, at 377.

37. Id. 
and be lost to the war effort." quarantined by the federal government, and thousands more by local authorities, on suspicion of spreading syphilis and gonorrhea, though many who found themselves behind barbed wire had neither disease." ${ }^{39}$ Certainly the power to quarantine "any woman" seems to be overly broad and cloaking an ulterior motive, that is, curbing prostitution among women. The adverse consequences to public health are that a health regulation was used for advancing morality and military goals, rather than solving genuine public health problems.

Similarly, in the early 1940 's, the U.S. Air force banned individuals with sickle cell trait (black fliers) on the grounds that this disorder could endanger the carrier and fellow crew members under hypoxic conditions, despite the fact that "medical literature had virtually eliminated sickle cell anemia as a hazard to the black aviator." $"$ This ban was not lifted until 1981, but only after a cadet filed a lawsuit. ${ }^{41}$ Again here the motive of the ban appears to have been ulterior, discrimination against African-American pilots. The harm to public health? Most likely, a distrust of the public health system by some African Americans.

More recently, in 2010, Congress passed the Patient Protection and Affordable Care Act ("ACA"). ${ }^{42}$ The ACA would later prove to be pivotal in the national elections from 2010 to $2014 .^{43}$ Indeed, so much money in political advertisements was spent against the ACA that it became among the most polarizing and political issues in the country. ${ }^{44}$ Succinctly put, public health was turned into partisan warfare. ${ }^{45}$

38. Id.

39. Gregg Gonsalves \& Peter Staley, Panic, Paranoia and Public Health-The AIDS Epidemic's Lessons for Ebola, 371 NEw. ENG. J. MeD. 2348, 2349 (2014) (citing Brandt, supra note 30).

40. John Hoberman, Darwin's Athletes: How Sport Has Damaged Black America AND Preserved the Myth of Race 71 (1997).

41. Richard Severo, Air Academy to Drop its Ban on Applicants with Sickle-Cell Gene, N.Y. Times (Feb. 4, 1981), http://www.nytimes.com/1981/02/04/us/air-academy-to-drop-its-ban-onapplicants-with-sickle-cell-gene.html [https://perma.cc/G2CQ-DL4V].

42. Patient Protection and Affordable Care Act, Pub. L. No. 111-148, 124 Stat. 119 (2010).

43. See generally Henry J. Aaron, The Midterm Elections-High Stakes for Health Policy, 363 New Eng. J. Med. 1685 (2010); Robert J. Blendon \& John M. Benson, Voters and the Affordable Care Act in the 2014 Election, 371 New EnG. J. Med. e31(1) (2013).

44. Blendon \& Benson, supra note 43, at e31(3) ("One often unrecognized factor . . is the extraordinary level of paid negative advertising opposing the ACA that has taken place since the law was enacted. A recent study reported that $\$ 445$ million had been spent for advertising related to the ACA through the beginning of 2014. Of that amount, [ninety-four percent] was expended on negative ad messages about this national law. Moreover, the large volume of advertisements against the ACA has continued throughout the campaign season, with 37,544 anti-ACA ads between August 1 and September 11, 2014.").

45. See Daniel Gitterman \& John Scott, "Obama Lies, Grandma Dies": The Uncertain Politics of Medicare and the Patient Protection and Affordable Care Act, 36 J. HeALth Pol. PoL'y \& L. 555, 556 (2011) ("But following adoption of the 2010 Patient Protection and Affordable Care 
Some writers have also noted that one of the most frequent uses of an ostensible public health activity, i.e., legislating severe requirements for freestanding clinics that perform abortions, has little to do with public health and everything to do with making abortions difficult to obtain, especially for lowincome women. ${ }^{46}$ The expressed rationale is greater safety. ${ }^{47}$ In July 2013 for example, the Texas legislature passed House Bill $2,{ }^{48}$ a sweeping abortion measure that forced seventy-five percent of the clinics in Texas to close, leaving just eight in a state of twenty-six million people. ${ }^{49}$

Finally, in early 2014, the largest Ebola virus disease outbreak occurred in West Africa and affected multiple countries. ${ }^{50}$ In September 2014, Thomas Eric Duncan, a Liberian citizen who traveled to Dallas, later developed Ebola symptoms and died. ${ }^{51}$ Two nurses who were caring for Mr. Duncan tested positive for Ebola after Mr. Duncan died. ${ }^{52}$ The nurses were treated successfully. ${ }^{53}$

Act (ACA), Republicans compounded these fears by using Medicare-related provisions in the ACA as grounds for attacking Democrats in the 2010 midterm elections. Republican candidates claimed that the law would gut the program by cutting [five-hundred billion dollars]. Claiming that the law only slowed spending, Democrats accused Republicans of distortion. As in prior health care debates, both parties used these and other reform provisions to engage in partisan warfare.").

46. See Grossman et al., supra note 5 ("Texas is only one of several states attempting to regulate abortion out of existence - a trend that should be deeply troubling to the medical community.").

47. Id. (stating "The law requires facilities to meet the standards of ambulatory surgery centers (ASCs) and mandates physicians to have admitting privileges at nearby hospitals. Proponents of the law claim it will improve safety, despite overwhelming evidence that abortions provided in outpatient clinics have a very low level of complications.").

48. H.R. 2, 83d Leg., 2d C.S. (Tex. 2013) (codified at Tex. Health \& SafeTy Code $\S \S$ 171.0031, 171.041-048, 171.061-064 (2013)). See Sandhya Somashekhar, Supreme Court Temporarily Blocks Texas Abortion Law, WASH. Post (June 29, 2015), https://www. washingtonpost.com/politics/supreme-court-temporarily-blocks-texas-abortionlaw/2015/06/29/da4e8b1e-1e96-11e5-aeb9-a411a84c9d55_story.html [https://perma.cc/58QTD399] (noting on June 29, 2015, the U.S. Supreme Court temporarily blocked parts of this law from taking effect). On June 27, 2016, the Supreme Court struck down Texas' two abortion restrictions. Whole Woman's Health v. Hellerstedt, 136 S. Ct. 2292, 2318-20 (2016).

49. Brian M. Rosenthal, U.S. Supreme Court Blocks Parts of Texas Abortion Law, Hous. CHron. (Oct. 14, 2014, 10:41 PM), http://www.chron.com/news/politics/texas/article/U-SSupreme-Courts-halts-parts-of-Texas-abortion-5822776.php [https://perma.cc/LM3G-FF97].

50. See 2014 Ebola Outbreak in West Africa-Outbreak Distribution Map, CTRS. FOR Disease CONTROL \& Prevention, http://www.cdc.gov/vhf/ebola/outbreaks/2014-westafrica/distribution-map.html\#areas [https://perma.cc/973X-NGKS] (last visited Mar. 31, 2017) (noting the affected countries included Guinea, Liberia, Mali, and Sierra Leone).

51. Greg Botelho \& Jacque Wilson, Thomas Eric Duncan: First Ebola Death in U.S., CNN (Oct. 8, 2014), http://www.cnn.com/2014/10/08/health/thomas-eric-duncan-ebola/ [https://perma.cc/K57G-5JJD].

52. Cases of Ebola Diagnosed in the United States, Ctrs. For Disease CONTROL \& Prevention (Dec. 16, 2014), http://www.cdc.gov/vhf/ebola/outbreaks/2014-west-africa/united- 
Despite the fact that only Mr. Duncan died from Ebola in the U.S., ${ }^{54}$ politicians and some local communities used the health crisis as a tool to scare the public, or to stigmatize people from the African continent, specifically those from West Africa. Some have described these actions as pure politics and not science. ${ }^{55}$

These examples from outside and within the U.S. show the pitfalls and risks of using public health for non-public health purposes. This is not, of course, to say that all the non-public health purposes are sinister, unethical or even unconstitutional. For example, using public health to improve educational outcomes is certainly permissible, even if education may be a non-public health purpose. ${ }^{56}$ What this Article addresses are questions of how far governments and individuals can and do go in using public health for what are ostensibly nonpublic health goals, and the unintended negative public health consequences of these actions. To help the reader understand these consequences, this Article provides a brief discussion of public health definitions and, what are and are not legitimate public health activities.

\section{What Are Legitimate Public Health Activities?}

In order to discuss the use of public health for non-public health activities, one needs to first define public health in general and public health activities in particular. Over the years, various definitions have been offered for public health. For example, the American Public Health Association (APHA) simply states that "[p]ublic health promotes and protects the health of people and the communities where they live, learn, work and play." ${ }^{, 57}$ The World Health Organization (WHO) defines public health as "[T] $[\mathrm{he}$ art and science of preventing disease, prolonging

states-imported-case.html [https://perma.cc/U4V3-XBVZ].

53. See Scott Pelley, Nurses Who Treated Ebola Patient Thomas Eric Duncan Tell Their Story, CBS NEws (Oct. 24, 2014), http://www.cbsnews.com/news/nurses-who-treated-ebolapatient-thomas-eric-duncan-tell-their-story/ [https://perma.cc/8PLE-88ZW].

54. Botelho \& Wilson, supra note 51.

55. Kate Zerninke \& Thomas Kaplan, Cuomo's and Christie's Shifts on Ebola Are Criticized as Politics, Not Science, N.Y. Times (Oct. 27, 2014), http://www.nytimes.com/2014/10/28/ nyregion/two-governors-shifts-on-ebola-are-criticized-as-politics-not-science.html [https://perma.cc/P86T-U74R].

56. See Brown, supra note 3, at 168 ("In the early 1990s, the Robert Wood Johnson Foundation created an ambitious ten-year Urban Health Initiative to improve the health and safety of children and youth. Leaders in the five cities it funded-Detroit, Oakland, Philadelphia, Richmond, and Baltimore - soon concluded that the most salient threats in question were violence, drugs, teen pregnancies, and other problems with which one coped by (for example) helping kids to stay in school instead of dropping out and offering appealing activities in the largely unsupervised after-school hours of 3-7 pm. These objectives had little to do with health institutions or public health, and much to do with school systems and the opaque set of voluntary institutions that constitute the after-school sector.").

57. What Is Public Health?, Am. PuB. HeAlth Ass'N, https://www.apha.org/what-is-publichealth [https://perma.cc/VK3G-U643] (last visited Mar. 31, 2017). 
life and promoting health through the organized efforts of society." 58 The CDC Foundation states that "[p]ublic health is the science of protecting and improving the health of families and communities through promotion of healthy lifestyles, research for disease and injury prevention and detection and control of infectious diseases." ${ }^{59}$ In a 1988 report, the Institute of Medicine (IOM) described public health as "what we as a society do collectively to assure the conditions in which people can be healthy." $"$ Although this is the widely accepted definition, some critics have charged that it is "a vague definition that fails to indicate the primary objective or scope of public health." 61

One overriding thread in these definitions is how broad they are. ${ }^{62}$ This makes it difficult to discern what legitimate public health activities are and what are not. ${ }^{63}$ Indeed,

[g]iven a widening understanding of health and the factors affecting prospects for population health, public health can be viewed as being so expansive as to have no meaningful institutional, disciplinary or social boundaries. Everything from crime, war and natural disasters; to population genetics, environmental hazards, marketing and other corporate practices; to political oppression, income inequality and individual behavior has been claimed under the rubric of public health. ${ }^{64}$

Still, an attempt can be made to describe parameters that constitute public health activities. Generally, public health activities: prevent epidemics and the spread of diseases, protect against environmental hazards, prevent injuries, promote and encourage healthy behaviors, respond to disasters and assist communities in recovery and assure the quality and accessibility of health services. ${ }^{65}$ Additionally, these activities involve specific legal authorization for conducting the activity as public health practice at the federal, state, or local levels; include a corresponding governmental duty to perform the activity to protect the public's health; involve direct performance or oversight by a governmental public health authority (or its authorized partner) and accountability to the public for its performance; may legitimately involve persons who did not specifically volunteer to participate and is supported by principles of public health ethics that focus on

58. Public Health, World Health Org., http://www.euro.who.int/en/health-topics/Healthsystems/public-health-services [https://perma.cc/EQ37-V8DR] (last visited Apr. 5, 2017).

59. What Is Public Health?, CDC FounD., http://www.cdcfoundation.org/content/whatpublic-health [https://perma.cc/8J9D-3D3Z] (last visited Mar. 31, 2017).

60. Inst. of Med., The Future of Public Health 1 (1988).

61. Mark A. Rothstein, Rethinking the Meaning of Public Health, 30 J. L. MED. \& ETHICS 144,145 (2002).

62. Id.

63. Id. at 148 .

64. Faden \& Shebaya, supra note 4.

65. See generally United States Public Health 101, Ctrs. FOr Disease Control \& PREVENTION, https://www.cdc.gov/stltpublichealth/docs/usph101.pptx [https://perma.cc/XJH3PXML] (last visited April 5, 2017). 
populations while respecting the dignity and rights of individuals ${ }^{66}$ Conversely, what does not fall under the above parameters cannot be considered legitimate public health activities. Thus, fictional vaccination programs, discriminatory quarantine orders, eugenics, and unethical medical experiments would not qualify. "Similarly, while reducing violence is critical to population health, that does not mean that law enforcement, the criminal justice system, diplomacy and international relations should be considered tools of public health." 67

In sum, to determine whether public health is being used for non-public health purposes, it is critical to clearly define what public health activities are. As noted by one commentator, "The key element of public health is the role of government-its power and obligation to invoke mandatory or coercive measures to eliminate a threat to the public's health." ${ }^{68}$ Therefore, in discussing its central theme, this Article will focus on the intersection of politics, public health, and law by exploring the non-public health purposes of the state anti-abortion legislations, the 2014 Ebola virus disease outbreak, and the Affordable Care Act.

\section{State Anti-Abortion Legislations aKa TARgeted Regulation of ABORTION PROVIDERS ("TRAP") LAWS}

In 2014, the Guttmacher Policy Review reported that a surge of state abortion restrictions put the providers and the women they serve in the crosshairs. ${ }^{69}$ The authors note that although abortion restrictions at the state level are hardly new, over a period of three years, however, "a startling number of states have passed harsh new restrictions. In 2011-2013, legislatures in 30 states enacted 205 abortion restrictions-more than the total number enacted in the entire previous decade. ${ }^{, 70}$ Between January and April 2015, more than 330 abortion restrictions were introduced in forty-three states. ${ }^{71}$ As of June 2016, "[t] $]$ here are thirty-one states that have at least one of the following abortion regulations: waiting periods, restrictions on health insurance coverage, bans after twenty weeks of pregnancy,

66. James G. Hodge \& Lawrence O. Gostin, Council of State \& Territorial Epidemiologists, Public Health Practice vs. Research (Mar. 24, 2004), http://www.cste2. org/webpdfs/CSTEPHResRptHodgeFinal.5.24.04.pdf [https://perma.cc/DL39-Q5AA].

67. Faden \& Shebaya, supra note 4.

68. Rothstein, supra note 61 , at 146.

69. Heather D. Boonstra \& Elizabeth Nash, A Surge of State Abortion Restrictions Puts Providers-And the Women They Serve-in the Crosshairs, 17 GutTMacher Pol'y Rev. 1, 9 (2014).

70. $I d$.

71. Dahlia Lithwick, Dismembered Protections: These New Abortion Bans May Be the Most Dangerous Yet, SLATE (Apr. 15, 2015), http://www.slate.com/articles/news_and_politics/ jurisprudence/2015/04/kansas_and_oklahoma_abortion_bans_second_trimester_abortions_will_ be_more.html [https://perma.cc/7LGY-A8VK]; see also Frances Robles, State Legislatures Put Up Flurry of Roadblocks to Abortion, N.Y. TIMES (May 8, 2015), http://www.nytimes.com/2015/05/ 09/us/politics/state-legislatures-put-up-flurry-of-roadblocks-to-abortion.html?_r=0 [https://perma.cc/7FGN-YSTK] ("This year [2015], more than 300 regulations were proposed in 45 states."). 
requirements that clinics meet ambulatory surgical center standards or requirements that abortion doctors have hospital admitting privileges." 72

In seeking to pass these TRAP laws, "antiabortion leaders disingenuously insist that these restrictions are necessary to protect women's health and safety."73 Almost uniformly, they pepper their statutes with medical and public health incantations such as women's health and safety ${ }^{74}$ informed consent,${ }^{75}$ unsafe abortion protection act, ${ }^{76}$ and the oddly titled Arkansas Human Heartbeat Protection Act. ${ }^{77}$ But as some federal courts have found, the medical grounds presented for these laws are usually "feeble" or "non-existent," prevailing scientific findings. ${ }^{79}$ For example, "Arkansas, along with Arizona, also

72. Denise Lu \& Sandhya Somashekar, Abortion Regulations by State, WASH. Post (June 1, 2016), https://www.washingtonpost.com/graphics/national/abortion-regulations/ [https://perma. cc/P252-RH5Y].

73. Boonstra \& Nash, supra note 69 , at 13.

74. See, e.g., Women's Health \& Safety Act, H.R. 57, 2013 Leg., Reg. Sess. (Ala. 2013) (enjoined in Planned Parenthood Southeast, Inc. v. Bentley, 951 F. Supp. 2d 1280 (M.D. Ala. 2013)).

75. See, e.g., ARIz. Rev. StAT. § 36-2158 (2016).

76. See, e.g., LA. REV. STAT. § 40:1299.35.2 (2016), invalidated by June Med. Servs. LLC v. Kliebert, 158 F. Supp. 3d 473 (M.D. La. 2016).

77. See Arkansas Human Heartbeat Protection Act, Ark. Code $\S \S 20-16-1301-1307$ (2013), invalidated by Edwards v. Beck, 786 F.3d 1113 (8th Cir. 2015), cert. denied, 136 S. Ct. 895 (2016).

78. See Planned Parenthood of Wis., Inc. v. Van Hollen, 738 F.3d 786, 798 (7th Cir. 2013) ("In this case the medical grounds thus far presented . . . are feeble, yet the burden great because of the state's refusal to have permitted abortion providers a reasonable time within which to comply.”); Planned Parenthood of Ariz., Inc. v. Humble, 753 F.3d 905, 917 (9th Cir. 2014) (stating "Here, the 'medical grounds thus far presented' are not merely 'feeble.' They are non-existent. On the current record, the Arizona law imposes an undue — and therefore unconstitutional — burden on women's access to abortion.”); Planned Parenthood Southeast, Inc. v. Strange, 9 F. Supp. 3d 1272, 1292 (M.D. Ala. 2014) (describing "The first flaw is some other courts' failure to consider all of the relevant circumstances. Particularly in examining regulations that, like subsection 4(c), have the potential to close down clinics which provide abortion services, some courts, whether they reached the correct result or not, have tended to pluck single, often easily quantifiable factors out of context and to hold them up as conclusive evidence that there is no undue burden."). $C f$. Tucson Woman's Clinic v. Eden, 379 F.3d 531, 557 n.2 (9th Cir. 2004) (finding the Plaintiffs submitted sufficient evidence to create an issue of material fact as to whether an Arizona law requiring the licensing and regulation of any medical facility in which five or more first trimester abortions in any month or any second or third trimester abortions are performed, creates an undue burden on the right to seek an abortion in violation of the United States Constitution, but also noting that "[s]ome doctors in deposition testimony indicated that they felt Lou Anne Herron's death was merely an 'excuse' for the law, which anti-abortion proponents had wanted for a long time. In light of the legislative history, however, plaintiffs must submit something more than the suspicion of doctors that there is an illegitimate purpose to the scheme.").

79. See Editorial Board, The Abortion Ban's Bogus Arguments, N.Y. Times (May 14, 2015), http://www.nytimes.com/2015/05/15/opinion/an-abortion-bans-bogus-arguments.html, 
passed the most novel requirement, requiring doctors to tell patients that druginduced abortions can be reversed, an assertion that many doctors say is wrong." 80 Several states (Alabama, Louisiana, Mississippi, and Texas, to mention but a few) have abortion bans at twenty weeks after the beginning of the last menstrual cycle on the ostensible principle that a fetus can feel pain at twenty weeks. ${ }^{81}$ However, researchers in a systematic multidisciplinary review of evidence found that "[f]etal awareness of noxious stimuli requires functional thalamocortical connections. Thalamocortical fibers begin appearing between [twenty-three] to [thirty] weeks' gestational age, while electroencephalography suggests the capacity for functional pain perception in preterm neonates probably does not exist before [twenty-nine] or [thirty] weeks." ${ }^{12}$ This would seem to render dubious the notion that a twenty-week-old fetus can feel pain.

Suzanne Goldberg, Director of the Columbia Law School Center for Gender and Sexuality Law, notes that "[s]tate legislatures are restricting how doctors provide medical care related to abortion, where doctors can provide that care, what doctors can say to patients when they provide that care and more." ${ }^{83}$ In 2012, for example, the Arizona legislature passed a law that required the director of the department of public health to adopt rules providing that "any medication, drug or other substance used to induce an abortion is administered in compliance with the protocol that is authorized by the United States food and drug administration ["FDA"] and that is outlined in the final printing labeling instructions for that medication, drug or substance." ${ }^{84}$ Planned Parenthood of Arizona challenged the law on the grounds that the Arizona law substantially burdened women's access to abortion services, and that Arizona introduced no evidence that the law advanced Arizona's interest in women's health in any way. ${ }^{85}$ The Ninth Circuit Court of Appeals found several problems with the law.

[https://perma.cc/2T7F-4AF2] (discussing the House's vote on the Pain-Capable Unborn Child Protection Act, and noting "the bill is not really about scientific findings of any sort. It is simply another attempt by conservative Republicans to undercut women's constitutionally protected reproductive rights. A 20 -week abortion ban would be a restriction before fetal viability that violates the Supreme Court's ruling in Roe v. Wade.").

80. Robles, supra note 71.

81. Abortion Bans at 20 Weeks: A Dangerous Restriction for Women, NARAL: PRO-CHOICE AM. (Jan. 1, 2016), http://www.prochoiceamerica.org/media/fact-sheets/abortion-bans-at-20weeks.pdf [https://perma.cc/KM4N-96Y4].

82. Susan J. Lee et al., Fetal Pain: A Systematic Multidisciplinary Review of the Evidence, 294 J. Am. Med. Ass'N 947, 947 (2005). But see Matthew A. Rysavy et al., Between-Hospital Variation in Treatment and Outcomes in Extremely Preterm Infants, 372 NEw ENG. J. MED. 1801, 1801 (finding "Differences in hospital practices regarding the initiation of active treatment in infants born at 22, 23, or 24 weeks of gestation explain some of the between-hospital variation in survival and survival without impairment among such patients.”).

83. Robles, supra note 71.

84. ARIZ. Rev. StAt. § 36-449.03(E)(6), as amended by 2016 Ariz. Legis. Serv. Ch. 75 (S.B. 1324) (2016).

85. Planned Parenthood of Ariz., Inc. v. Humble, 753 F.3d 905 (9th Cir.), cert. denied, 135 
The court noted that the FDA "neither prohibit[s] nor discourage[s] off-label use of FDA-approved drugs. In fact, the FDA has repeatedly acknowledged that offlabel use is common and is sometimes required by good medical practice." ${ }^{" 86}$ The "district court found that the Arizona legislature provided no supporting evidence for any asserted legislative fact." $" 87$

To be fair, not every abortion restriction imposed by the states is unconstitutional or even burdensome.$^{88}$ It is reasonable and appropriate to argue that state legislatures have a legitimate interest, indeed a constitutional one, in responding to their constituents' concerns, be they pro- choice or pro-life. But in responding to these concerns, it is clear that the laws are heavily tilted in favor of anti-abortion groups, ${ }^{89}$ sometimes to the detriment of public health. ${ }^{90}$

\section{A. Implications for Public Health Practice}

The implications of these anti-abortion legislations on public health practice can be significant. Laws aimed at abortion impede medical care for women more generally. ${ }^{91}$ Commenting on the increasing number of abortion restrictions introduced into state legislatures since January 2015 , one critic opines that these anti-abortion legislations

S. Ct. 870 (2014).

86. Id. (citations omitted).

87. Id. at 910 (citations omitted).

88. See, e.g., Gonzalez v. Carhart, 550 U.S. 124 (2007) (upholding the validity of the PartialBirth Abortion Ban Act of 2003, a federal statute regulating abortion procedures); Planned Parenthood of Southeastern Pa. v. Casey, 505 U.S. 833 (1992) (holding the state has legitimate interests from the outset of the pregnancy in protecting the health of the woman and the life of the fetus that may become a child).

89. See Mitch Smith, Indiana Governor Signs Abortion Bill with Added Restrictions, N.Y. TiMEs (Mar. 24, 2016), http://www.nytimes.com/2016/03/25/us/indiana-governor-mike-pencesigns-abortion-bill.html?_r=0 [https://perma.cc/R6EP-W58E] (noting "Indiana's governor signed a bill ... that adds broad limits to women's access to abortions, banning those motivated solely by the mother's objection to the fetus's race, gender or disability, and placing new restrictions on doctors. The law ... was cheered by anti-abortion groups that had encouraged Gov. Mike Pence to sign it.").

90. See Editorial Board, supra note 79 (noting that "[m]aking it hard to get an abortion early in a pregnancy - by restricting the use of health insurance for abortion, closing clinics and mandating waiting periods - and then banning the procedure after 20 weeks would essentially prohibit abortion for those with limited resources").

91. See, e.g., Planned Parenthood Southeast, Inc. v. Strange, 33 F. Supp. 3d 1381, 1392 (M.D. Ala, 2014) (Dr. Lori Freedman testifying for plaintiffs about the stigma against abortion providers and how this stigma creates obstacles to finding doctors willing to perform abortions); Maya Manian, The Side Effects of Abortion Restrictions, For The Conference on Liberty/Equality: The View From Roe's 40th and Lawrence's 10th Anniversaries, BALKINIZATION (Jan. 18, 2013), https://balkin.blogspot.com/2013/01/the-side-effects-of-abortion_18.html [https://perma.cc/8DXA$\mathrm{P} 3 \mathrm{C} 4]$ (noting "as a matter of medical reality, abortion cannot be isolated from the continuum of women's healthcare"). 
are of a piece with the national movement to intimidate and harass physicians, with strategies that range from forcing them to perform unwanted ultrasounds and read from factually flawed "informed consent" scripts, to forcing them to obtain admitting privileges at local hospitals (which may refuse to provide them) — or new efforts to simply refuse to let doctors learn about abortion in the first place. ${ }^{92}$

Of all the restrictive abortion legislations, two states' statutes, Texas and Wisconsin, merit discussion here for their harsh restrictions, their significant impacts on public health practice, and the contrasting appellate decisions in their respective federal courts of appeal. The Texas statute, commonly referred to as House Bill 2 ("H.B. 2") provides in pertinent part that "a physician performing or inducing an abortion must, on the date the abortion is performed or induced, have active admitting privileges at a hospital that is located within 30 miles from the location at which the abortion is performed" 93 and that "the minimum standards for an abortion facility must be equivalent to the minimum standards adopted under [the Texas Health and Safety Code section] for ambulatory surgical centers. ${ }^{" 94}$ Planned Parenthood of Greater Texas Surgical Health Services and other abortion facilities sued the State seeking to enforce their rights and those of patients for declaratory judgment and to enjoin two provisions in the statute pertaining to the regulation of surgical abortions and abortion-inducing drugs. $^{95}$

The district court found "no rational basis for the new provision and condemned it as having a purpose or effect to stymie women's abortion access." Among others, the district court "found 'no evidence' that admitting privileges to a hospital within thirty miles of the abortion provider's clinic 'address issues of patient abandonment, hospital costs, or accountability.","97 The Fifth Circuit Court of Appeals reversed, finding that "admitting-privileges requirement, as enacted, has a rational basis." ${ }^{.98}$ Despite evidence from Plaintiffs' experts about the negative impacts of the admitting privileges rule, the Fifth Circuit reasoned that the State's articulation of rational legislative objectives, which was backed by evidence placed before the state legislature, ${ }^{99}$ easily supplied a connection

92. Lithwick, supra note 71.

93. TeX. HEALTH \& SAFETY CODE $§ 171.0031$ (a)(1) (2013), held unconstitutional by Whole Woman's Health v. Hellerstedt, 136 S. Ct. 2292 (2016).

94. Id.

95. Whole Woman's Health, 136 S. Ct. at 2300-01.

96. Planned Parenthood of Greater Tex. Surgical Health Servs. v. Abbott, 748 F.3d 583, 593

(5th Cir. 2014), reversed and remanded in Whole Woman's Health, 136 S. Ct. at 2320.

97. Id. (quoting Planned Parenthood of Greater Tex. Surgical Health Servs. v. Abbott, 951 F. Supp. 2d 891, 900 (W.D. Tex. 2013)).

98. Id. at 594.

99. Evidence placed before the legislature included testimony from Dr. Love, Chairman of the Ob/Gyn section of St. David's Medical Center in Austin that "the general standard of care requires hospital privileges for physicians who perform abortions." Id. at 594. At trial, "the State 
between the admitting-privileges rule and the desirable protection of abortion patients' health, noting somewhat wryly that "[a] law 'based on rational speculation unsupported by evidence or empirical data' satisfies rational basis review." ${ }^{100}$ In so ruling, the Fifth Circuit was unpersuaded by a decision from the Seventh Circuit Court of Appeals in Planned Parenthood of Wisconsin, Inc. v. Van Hollen ${ }^{101}$ addressing a similarly worded statute in $\mathrm{W}$ isconsin. The Wisconsin statute in question provides that "[n]o physician may perform an abortion, as defined in $\S 253.10$ (2) (a), unless he or she has admitting privileges in a hospital within 30 miles of the location where the abortion is to be performed." 102 Planned Parenthood of Wisconsin and Milwaukee Women's Medical Services filed suit challenging the constitutionality of the $\mathrm{W}$ isconsin statute under 42 U.S.C. $\S 1983$ (2012), "which provides a tort remedy for violations of federal law by state employees." 103 The district court granted a preliminary injunction. ${ }^{104}$ On appeal, the reviewing court addressed the question of whether the district judge was justified in entering the preliminary injunction. ${ }^{105}$ The reviewing court affirmed the trial court, but more significantly found that

[h] ad enforcement of the statute not been stayed, two of the state's four abortion clinics ... would have had to shut down because none of their doctors had admitting privileges at a hospital within the prescribed 30mile radius of the clinics, and a third clinic would have lost the services of half its doctors. The impossibility of compliance with the statute even by doctors fully qualified for admitting privileges is a compelling reason for the preliminary injunction, albeit a reason that diminishes with time. ${ }^{106}$

Additionally, the appellate court faulted Wisconsin's counsel for failure to cite "medical or statistical evidence." 107 Indeed, the court cited, with approval, the district judge's footnote, which stated,

[T] he complete absence of an admitting privileges requirement for clinical [i.e., outpatient] procedures including for those with greater risk is certainly evidence that Wisconsin Legislature's only purpose in its enactment was to restrict the availability of safe, legal abortion in this State, particularly given the lack of any demonstrable medical benefit for

established that the admitting-privileges requirement was based on the rational speculation, if not empirical data, that the regulation would assist in preventing patient abandonment by the physician who performed the abortion and then left the patient to obtain care if complications developed." Id. at 593-94 (citations omitted).

100. Id. at 594 (quoting F.C.C. v. Beach Commc'ns, Inc., 508 U.S. 307, 315 (1993)).

101. 738 F.3d 786 (7th Cir. 2013).

102. Wis. STAT. $§ 253.095(2)$ (2016).

103. Van Hollen, 738 F.3d at 788.

104. Id.

105. $I d$.

106. Id. at 789 .

107. Id. at 790 . 
its requirement either presented to the Legislature or [to] this court. ${ }^{108}$

In departing from the Seventh Circuit's holding, the Fifth Circuit noted:

To the extent that Van Hollen's lengthy discussion of the merits of the Wisconsin law conflicts with our ruling, however, we are unpersuaded by the concerns of the majority. Van Hollen faults the state of Wisconsin for not adducing statistical evidence that the admitting-privileges requirement will make abortions safer. It complains that the record includes no evidence that abortion complications are underreported, that these complications require continuity of care more than other outpatient services, or that women who have complications from an abortion [receive] better care if their abortion provider has hospital privileges. The first-step in the analysis of an abortion regulation, however, is rational basis review, not empirical basis review. . . By suggesting that Wisconsin needed to offer factual or statistical evidence, Van Hollen ignored case law from its own circuit holding, consistent with the Supreme Court's oft-repeated guidance, that there is "never a role for evidentiary proceedings" under rational basis review. ${ }^{109}$

So, is this a case of no medical or statistical evidence from supporters of antiabortion legislation as found by the Van Hollen court, or is it a question of the legislature simply articulating a rational basis for its statute regardless of the purpose of the law, as held by the Fifth Circuit in Abbott? ${ }^{110}$

For public health purposes, the argument that a legislature need only articulate rational basis for any public health measure, regardless of intent, could be a double-edged sword. Whereas using a law to advance public health goals is rational, using public health as a pretext to advance a law, in this case, making

108. Id. (alteration in original) (quoting Planned Parenthood of Wis. v. Van Hollen, No. 13-cv465-wmc, 2013 U.S. Dist. LEXIS 110097, at*40 n. 26 (W.D. Wis. Aug. 2, 2013)).

109. Planned Parenthood of Greater Tex. Surgical Health Servs. v. Abbott, 748 F.3d 583, 598 (5th Cir. 2014) (quotation marks and citations omitted), reversed and remanded in Whole Woman's Health v. Hellerstedt, 136 S. Ct. 2292, 2320 (2016)).

110. In criticizing the Fifth Circuit's use of the rational basis test in Abbott, the Ninth Circuit noted, in pertinent part:

In Abbott, the Fifth Circuit held that courts may not consider the strength of the state's justification, stating that an abortion regulation need only be supported by "rational speculation." In DeWine, the Sixth Circuit analyzed whether an Ohio abortion regulation was an undue burden without considering the strength of the state's justification for the regulation. We conclude that Abbott and DeWine are inconsistent with the undue burden test as articulated and applied in Casey and Gonzales. The Fifth and Sixth Circuits' approach fails to recognize that the undue burden test is contextspecific, and that both the severity of a burden and the strength of the state's justification can vary depending on the circumstances. We adhere to the approach in Eden and Van Hollen, which requires us to weigh the extent of the burden against the strength of the state's justification in the context of each individual statute or regulation.

Planned Parenthood of Ariz., Inc. v. Humble, 753 F.3d 905, 914 (2014). 
abortions illegal, certainly is not. Indeed, Judge Posner captured this pre-textual reason in Van Hollen when he noted,

It has been 40 years since Roe v. Wade, ${ }^{111}$ was decided, legalizing (most) abortion throughout the United States, and it could not have taken the State of Wisconsin all this time to discover the supposed hazards of abortions performed by doctors who do not have admitting privileges at a nearby hospital. ${ }^{112}$

One may ask the same question of the other states with laws identical to Wisconsin and Texas, e.g., Alabama, ${ }^{113}$ Mississippi, ${ }^{114}$ Missouri, ${ }^{115}$ North Dakota, ${ }^{116}$ and Tennessee. ${ }^{117}$ Did it take them approximately forty to forty-two years to discover the supposed hazards of abortions performed by doctors who do not have admitting privileges at a nearby hospitals? ${ }^{118}$ Or is this, as the central thesis of this paper posits, the use of public health for non-public health purposes? One would not be too far off the mark to conclude that these laws are principally anchored on animus towards Roe v. Wade rather than on solutions to genuine public health problems. ${ }^{119}$ Two years after Van Hollen, ${ }^{120}$ the Seventh Circuit decided Planned Parenthood of Wisconsin, Inc. $v$ Schimel. ${ }^{121}$ In affirming the trial

111. 410 U.S. 113 (1973).

112. Van Hollen, 738 F.3d at 793.

113. Ala. CODE § 26-23E-4(c) (2013), held unconstitutional by Planned Parenthood Southeast, Inc. v. Strange, 172 F. Supp. 3d 1275, 1292 (M.D. Ala. 2016).

114. Miss. Code $§$ 41-75-1(f) (2013), amended by 2016 Miss. Laws S.B. 2297.

115. Mo. ReV. STAT. $\$ 188.080$ (2016).

116. N.D. CENT. CODE $§ 14-02.1-04(1)$ (2016).

117. TenN. CoDE. § 39-15-202 (1997), held unconstitutional in part by Planned Parenthood of Middle Tenn. v. Sundquist, 38 S.W.3d 1 (Tenn. 2000).

118. There is an equally strong counterargument to the assertion that it took over forty to fortytwo years for state legislatures to discover the supposed hazards of abortions performed by doctors who do not have admitting privileges at a nearby hospitals. The fact that it has taken this long for the legislatures to act does not mean that the result is invalid or even unconstitutional. For example, in a scornful dissent in the opinion legalizing same sex marriage, Justice Scalia noted:

The five Justices who compose today's majority are entirely comfortable concluding that every State violated the Constitution for all of the 135 years between the Fourteenth Amendment's ratification and Massachusetts' permitting of same-sex marriages in 2003. They have discovered in the Fourteenth Amendment a 'fundamental right' overlooked by every person alive at the time of ratification, and almost everyone else in the time since. They see what lesser legal minds - minds like Thomas Cooley, John Marshall Harlan, Oliver Wendell Holmes, Jr., Learned Hand, Louis Brandeis, William Howard Taft, Benjamin Cardozo, Hugo Black, Felix Frankfurter, Robert Jackson, and Henry Friendly - could not.

Obegerfell v. Hodges, 135 S. Ct. 2584, 2639 (2015) (Scalia, J., dissenting).

119. See generally Lithwick, supra note 71.

120. 738 F.3d 786 (7th Cir. 2013).

121. 806 F.3d 908 (7th Cir. 2015). 
court's issue of a permanent injunction in Van Hollen, ${ }^{122}$ the Schimel court cited the trial court with approval, noting that

the district judge had remarked in granting the preliminary injunction that while he would await trial on the issue, ... the complete absence of an admitting privileges requirement for other clinical [i.e., outpatient] procedures including for those with greater risk than abortion is certainly evidence that the Wisconsin Legislature's only purpose in its enactment was to restrict the availability of safe, legal abortion in this State, particularly given the lack of any demonstrable medical benefit for its requirement either presented to the Legislature or [to] this court. ${ }^{123}$

Finally, to underscore the point that the Wisconsin legislature was using women's health to advance its agenda against abortion rather than for legitimate public health purposes, Judge Posner warned,

Until and unless Roe v. Wade is overruled by the Supreme Court, a statute likely to restrict access to abortion with no offsetting medical benefit cannot be held to be within an enacting state's constitutional authority. The courts have "an independent constitutional duty to review [a legislature's] factual findings where constitutional rights are at stake." The Wisconsin statute does not "further[] the legitimate interest" of the state in advancing women's health, and it was not "reasonable for [the legislature] to think" that it would. ${ }^{124}$

\section{B. The Supreme Court Brings Down the Curtain: A Win For Science?}

On June 27, 2016, the Supreme Court ruled against Texas, striking down the admitting privileges and surgical center requirements as placing undue burden on abortion access and, therefore, violating the Federal Constitution as interpreted in Planned Parenthood of Southeastern Pennsylvania v. Casey. ${ }^{125}$ In the decision, the majority cited with approval the district court's findings in Whole Woman's Health v. Lakey, ${ }^{126}$ noting that there is adequate legal and factual support for the district court's conclusion that the legislative change imposed an undue burden on a woman's right to have an abortion. ${ }^{127}$ Some of the pertinent district court findings cited by the Supreme Court are as follows:

122. Planned Parenthood of Wis., Inc. v. Van Hollen, No. 13-cv-465-wmc, 2013 U.S. Dist. LEXIS 110097 (W.D. Wis. Aug. 2, 2013).

123. Schimel, 806 F.3d at 915.

124. Id. at 916 (quoting Gonzales v. Carhart, 550 U.S. 124, 163-65, 146, 160 (2007)).

125. Whole Woman's Health v. Hellerstedt, 136 S. Ct. 2292, 2300 (2016) (citing Planned Parenthood of Southeastern Pa. v. Casey, 505 U.S. 833, 878 (1992)).

126. Id. at 2310-11 (citing Whole Woman's Health v. Lakey, 46 F. Supp. $3 d 673$ (2014)). This case was filed a week after the Fifth Circuit Court of Appeals issued its decision in Planned Parenthood of Greater Texas Surgical Health Services v. Abbott, 748 F.3d 583 (2014). See Whole Woman's Health, 136 S. Ct. at 2301.

127. Id. at 2310-11. 
3. Prior to the enactment of H. B. 2, there were more than 40 licensed abortion facilities in Texas, which "number dropped by almost half leading up to and in the wake of enforcement of the admitting-privileges requirement that went into effect in late-October 2013."

4. If the surgical-center provision were allowed to take effect, the number of abortion facilities, after September 1, 2014, would be reduced further, so that "only seven facilities and a potential eighth will exist in Texas."

...

10. "The great weight of evidence demonstrates that, before the act's passage, abortion in Texas was extremely safe with particularly low rates of serious complications and virtually no deaths occurring on account of the procedure."

11. "Abortion, as regulated by the State before the enactment of House Bill 2, has been shown to be much safer, in terms of minor and serious complications, than many common medical procedures not subject to such intense regulation and scrutiny."

$$
\text { ... }
$$

13. "[W]omen will not obtain better care or experience more frequent positive outcomes at an ambulatory surgical center as compared to a previously licensed facilities." ${ }^{28}$

Justice Breyer, writing for the majority, observed that

On the basis of these and other related findings, the District Court determined that the surgical-center requirement "imposes an undue burden on the right of women throughout Texas to seek a previability abortion," and that the "admitting-privileges requirement, . . . in conjunction with the ambulatory-surgical-center requirement, imposes an undue burden on the right of women in the Rio Grande Valley, El Paso, and West Texas to seek a previability abortion." 129

So what does this mean for public health? First, in addressing the constitutional question, Justice Breyer rejected Texas's argument that the provisions were not anti-abortion laws, but were simply designed to promote women's health. Justice Breyer noted that "the surgical-center requirement, like the admitting-privileges requirement, provides few, if any, health benefits for women." 130

Second, this decision can be viewed as a win for science. ${ }^{131}$ This is, in part,

128. Id. at 2301-02 (quoting Whole Woman's Health v. Lakey, 46 F. Supp. 3d at 680, 681, $684)$.

129. Id. at 2303 (quoting Whole Woman's Health, 46 F. Supp. $3 \mathrm{~d}$ at 687).

130. Id. at 2318 .

131. Ariana Eunjung Cho, Supreme Court Rules Against Texas and for Science in Abortion 
because the majority relied heavily on the findings of facts by the district court discussed above. ${ }^{132}$ The district court provided sufficient data and statistics to support its conclusion that the challenged provisions impose an undue burden on women. For example, one statistic that undermines Texas' argument of protecting women's health is that

[A]bortion, as regulated by the State before the enactment of House Bill 2 , has been shown to be much safer, in terms of minor and serious complications, than many common medical procedures not subject to such intense regulation and scrutiny such as colonoscopies, vasectomy and endometrial biopsy, and plastic surgery. ${ }^{133}$

Justice Ginsburg, in her concurrence, cited the Brief for American College

of Obstetricians and Gynecologists ("ACOG”) as an amicus curiae that concluded that abortion is one of the safest medical procedures performed in the United States; and the Brief for Social Science Researchers comparing statistics on risks for abortion, with tonsillectomy, colonoscopy, and in-office dental surgery, which showed complication rates from abortion are, relatively, very low. ${ }^{134}$ Justice Breyer also cited the same ACOG Brief and the Brief for Medical Staff Professionals and Society of Hospital Medicine, on requirements of admitting privileges $;{ }^{135}$ underscoring the importance of medical data to the majority's decision. As one legal commentator put it, "in the decision, evidence-based medicine meets evidence-based law." ${ }^{136}$

Third, the argument advanced by Texas that legislatures and not courts, must resolve questions of medical uncertainty was rejected by the Court. ${ }^{137}$ Writing for the majority, Justice Breyer noted that " $[\mathrm{t}]$ he statement that legislatures, and not courts, must resolve questions of medical uncertainty is also inconsistent with this Court's case law." ${ }^{138}$ Succinctly put, courts should independently evaluate medical evidence without simply deferring to legislatures.

Finally, the majority decision, at least for the moment, puts a brake on TRAP laws. In fact, Justice Ginsburg, in her concurring opinion, forcefully stated that

[s]o long as this Court adheres to Roe v. Wade and Planned Parenthood

Case, WASH. Post (June 27, 2016), https://www.washingtonpost.com/news/to-yourhealth/wp/2016/06/27/the-supreme-court-rules-against-texas-and-for-science-in-abortion-case/ [https://perma.cc/FU5H-FEUH].

132. See Whole Woman's Health, 136 S. Ct. at 2301-02.

133. Id. at 2302 .

134. Id. at 2320 (Ginsberg, J., concurring).

135. Id. at 2312-13 (majority opinion).

136. Linda Greenhouse, The Facts Win Out on Abortion, N.Y. Times (June 27, 2016), http://www.nytimes.com/2016/06/28/opinion/the-facts-win-out-on-abortion.html? action $=$ click\&pgtype $=$ Homepage $\&$ clickSource $=$ story-heading $\&$ module $=$ opinion-c-col-leftregion \&region=opinion-c-col-left-region $\& W T . n a v=$ opinion-c-col-left-region \&_r $=0$ [https://perma.cc/6VHQ-MWJW].

137. Whole Woman's Health, 136 S. Ct. at 2312-13.

138. Id. at 2310 . 
of Southeastern Pa. v. Casey, Targeted Regulation of Abortion Providers

laws like H. B. 2 that "do little or nothing for health, but rather strew impediments to abortion," cannot survive judicial inspection. ${ }^{139}$

It is likely that states with laws similar to the Texas regulations will face challenges in courts. But it will not spell the end of using public health to advance either a pro-choice or anti-abortion agenda. Abortion truly is about politics, and in a nation as divided as ours, each side undoubtedly will shift its tactics in response to the Supreme Court's decisions. But inexorably one conclusion follows, illegitimate or illicit objectives in the name of public health will continue to constrain a woman's choice to continue or terminate a pregnancy.

A second example of manipulation of public health for non-public health purposes emerged in the 2014 Ebola Virus Disease outbreak, to which this Article now turns.

\section{The 2014 Ebola Virus Disease (EVD) OUtbreak}

On March 21, 2014, the Guinea Ministry of Health reported the outbreak of an illness characterized by fever, severe diarrhea, vomiting, and a high casefatality rate. ${ }^{140} \mathrm{~V}$ iral sequencing identified the Ebola virus (Zaïre ebolavirus) as the cause. ${ }^{141}$ "Ebola virus disease (EVD) is a complex zoonosis that is highly virulent in humans." 142 It is characterized by the sudden onset of fever and malaise, accompanied by other nonspecific signs and symptoms such as myalgia, headache, vomiting, and diarrhea. ${ }^{143}$ The disease quickly spread to other West African countries including Liberia, Sierra Leone, Nigeria, and Senegal. ${ }^{144}$ It is the onset of the disease in the U.S. that concerns the central thesis of this Article.

In September 2014, Thomas Eric Duncan, a Liberian citizen traveled to Dallas, Texas, developed Ebola symptoms and died. ${ }^{145}$ Duncan did not have symptoms when leaving Liberia, but developed them approximately four days after arriving in the United States. ${ }^{146} \mathrm{He}$ sought medical care at Texas Presbyterian Hospital of Dallas after developing symptoms consistent with Ebola. Mr. Duncan passed away on October 8, 2014. ${ }^{147}$ On October 10, 2014, a

139. Id. at 2321 (Ginsburg, J., concurring) (internal citations omitted) (quoting Planned Parenthood of Wis. v. Schimel, 806 F.3d. 908, 921 (2015)).

140. Meredith G. Dixon \& Ilana J. Schafer, Ebola Viral Disease Outbreak-West Africa, 2014, 63 Morbidity \& Mortality WKly. ReP. 537, 548 (June 27, 2014), https://www.cdc.gov/ mmwr/pdf/wk/mm6325.pdf [https://perma.cc/R86G-MBWP].

141. Id.

142. David Pigott et al., Mapping the Zoonotic Niche of Ebola Virus Disease in Africa, ELIFE (Sept. 8, 2014), https://elifesciences.org/content/3/e04395 [https://perma.cc/2FNY-NRGP].

143. Dixon \& Schafer, supra note 140.

144. P.K. Tosh \& P. Sampathkumar, What Clinicians Should Know About the 2014 Ebola Outbreak, 89 MAYO CLINIC PROC. 1710, 1710 (2014).

145. Botelho \& Wilson, supra note 51.

146. See Cases of Ebola Diagnosed in the United States, supra note 52.

147. Id. 
healthcare worker at Texas Presbyterian Hospital who provided care to Mr. Duncan, tested positive for Ebola. ${ }^{148}$ The next day, a second healthcare worker who provided care to him at the same hospital tested positive for Ebola. ${ }^{149} \mathrm{On}$ October 23, 2014, the New York City Department of Health and Mental Hygiene reported a case of Ebola in a medical aid worker who had returned to New York City from Guinea, where the medical aid worker had served with the medical humanitarian organization, Doctors Without Borders. ${ }^{150}$

Despite the fact that none of the healthcare workers or the medical aid worker died, the advent of Ebola virus in the homeland created an immense fear, albeit overblown, among the media, the politicians, and the public at large. ${ }^{151}$ This fear could be partly attributed to xenophobia and American exceptionalism. Examples of that fear ranged from parents in Mississippi pulling their children out of a middle school after finding out that its principal had traveled to Zambia-a nation that though is in Africa, did not record a single Ebola case; ${ }^{152}$ a Texas congressional candidate suggesting "a citywide 'no handshakes, no hugs' policy for Dallas"; to two young brothers from Senegal who were beaten by classmates on their Bronx school playground as they were being teased for being from Africa and having Ebola. ${ }^{153}$ Others opined that Ebola could become a bioterrorist threat, despite evidence to the contrary. ${ }^{154}$ In fact, "a November 2014 opinion poll revealed that the U.S. public ranked Ebola as the third-most urgent health problem facing the country-just below cost and access and higher than any other disease, including cancer or heart disease, which together account for nearly half of all U.S. deaths each year." minds of Americans, far bigger than the actual threat it posed to public health in

148. $I d$.

149. Id.

150. Id.

151. Sydney Lupkin \& Gillian Mohney, Ebola Outbreak Worsens with Missing Patients, US Scare, ABCNews (Feb. 2, 2017, 7:42 PM), http://abcnews.go.com/Health/ebola-outbreak-worsensmissing-patients-us-scare/story?id=25024218 [https://perma.cc/P98Q-3378].

152. Bryan Walsh, Why Ebola Isn't Really a Threat to the U.S., TIME (Oct. 21, 2014), http://time.com/3525385/ebola-threat-us-cdc/ [https://perma.cc/DB3J-EJ7A].

153. Sarah Kellogg, Infectious Disease Outbreak Response. Legal and Policy Challenges, D.C. BAR (Apr. 2015), https://www.dcbar.org/bar-resources/publications/washingtonlawyer/articles/april-2015-infectious-disease.cfm [https://perma.cc/N8ZJ-2GP8].

154. Dina Fine Maron, Weaponized Ebola: Is It Really a Bioterror Threat?, ScI. Am. (Sept. 25, 2014), http://www.scientificamerican.com/article/weaponized-ebola-is-it-really-a-bioterrorthreat/ [https://perma.cc/Q2V9-XCXT] ("Ebola's exponential spread has rekindled fears that terrorists may seek to turn the virus into a powerful weapon of mass destruction. Such talk has occurred on Capitol Hill and in national security circles. But the financial and logistical challenges of transforming Ebola into a tool of bioterror makes the concern seem overblown - at least as far as widespread devastation is concerned.").

155. Gillian K. SteelFisher et al., Ebola in the United States-Public Reactions and Implications, 373 NEW ENG. J. MED. 789, 789 (2015). 
2014." ${ }^{156}$

Even more troublesome than the examples cited above, were the politicians, policy makers, and some local community leaders who used the health crisis as a tool to scare the public or to stigmatize people from the African continent, specifically those from West Africa ${ }^{157}$ For example, many politicians called for travel bans among people from West Africa even though there were no direct flights between the countries dealing with an Ebola outbreak and the United States. ${ }^{158}$ Governors of several states issued their own policies, ${ }^{159}$ including mandatory quarantines of health care workers returning from West Africa who were exposed to Ebola patients. ${ }^{160}$ The Governors of New York and New Jersey said they were imposing a strict new mandatory quarantine because standards from the $\mathrm{CDC}$ were inadequate. ${ }^{161}$ These quarantine policies were in conflict with recommendations from the nation's top health experts and went beyond federal policy. ${ }^{162}$ These actions have been described as pure politics and not science. ${ }^{163}$ This assertion is supported by the fact that the Ebola outbreak coincided with the lead up to the November 3 national elections that significantly increased the

156. Kellogg, supra note 153.

157. See Gonsalves \& Staley, supra note 39 (noting "the current national panic over Ebola brings back some very bad memories ... the amplification of these reactions by politicians and the media, and the fear-driven suspicion and shunning of whole classes of people are all reminiscent of the response to the emergence of AIDS in the 1980s"); Andrew Siddons, Panel's G.O.P. Chairman Steps Up Criticism of Ebola Response, N.Y. TIMES (Oct. 24, 2014), http://www.nytimes.com/2014/10/25/us/politics/administrations-ebola-response-draws-scrutiny-ofhouse-committee.html?_r=0 [https://perma.cc/M57A-9YHU] (explaining "Representative Trey Gowdy, Republican of South Carolina, is one of several lawmakers who have recently called on President Obama to block foreigners in the Ebola-affected countries from coming to the United States.").

158. Jaime Fuller, The Ebola Travel Ban Is Really Politically Popular. Here's Why It's Not Happening, WASH. POST (Oct. 20, 2014), https://www.washingtonpost.com/news/thefix/wp/2014/10/20/the-ebola-travel-ban-is-really-popular-heres-why-its-not-happening/ [https://perma.cc/NY3D-TLEL].

159. For example, on October 27, 2014, Georgia Governor Nathan Deal announced that Georgia would increase Ebola monitoring for all in-bound travelers from affected countries. See Deal Issues New Policy for Travelers from Ebola-affected Countries, Gov.GEORGIA.Gov (Oct. 27, 2014), https://gov.georgia.gov/press-releases/2014-10-27/deal-issues-new-policy-travelers-ebolaaffected-countries [https://perma.cc/2WUG-J2ZW].

160. Dennis Thompson, N.Y., N.J. Ease Ebola Quarantines, Health Day (Oct. 27, 2014), https://consumer.healthday.com/public-health-information-30/government-health-news-339/n-y-nj-ease-ebola-quarantines-693109.html [https://perma.cc/UN5Z-AMTB].

161. Zerninke \& Kaplan, supra note 55.

162. Anemona Hartocollis, Notable Absence of New Ebola Quarantines at New York Area Airports, N.Y. Times (Nov. 23, 2014), http://www.nytimes.com/2014/11/24/nyregion/notableabsence-of-new-ebola-quarantines-at-new-york-area-airports.html [https://perma.cc/D88M-ZKS7].

163. Zerninke \& Kaplan, supra note 55. 
partisan rhetoric. ${ }^{164}$

\section{A. Implications for Public Health Practice}

The use of the Ebola health crisis for non-public health purposes-in this case to pander to voters during the 2014 midterm elections ${ }^{165}$ - is dangerous in principle and doubly unsupportive of the nation's public health agenda. For example, some members of Congress used the crisis to step up their criticisms of the $\mathrm{CDC}$, and the Obama administration in general. ${ }^{166}$ President Obama, in return, attacked critics of his response to Ebola. ${ }^{167}$ The end result is harm to public health by turning it into a partisan issue which it should not be. Dr. Craig Spencer, the first U.S. health worker diagnosed with Ebola after a brief asymptomatic period here in the United States, ${ }^{168}$ writing about injection of politics into Ebola observed that

politicians, caught up in the election season, took advantage of the panic to try to appear presidential instead of supporting a sound, science-based public health response. . . The threat of quarantine may cause sick people to defer seeking treatment, and both nationals of affected countries and health care responders returning from those countries may alter their travel plans or misreport their exposure to avoid quarantine. Implementing restrictions that don't accord with the recommendations of the Centers for Disease Control and Prevention also undermines and erodes confidence in our ability to respond cohesively to public health crises. At times of threat to our public health, we need one pragmatic response, not 50 viewpoints that shift with the proximity of the next election. Moreover, if the U.S. public policy response undermined efforts to send more volunteers to West Africa, and thus allowed the outbreak to continue longer than it might have, we would all be culpable. ${ }^{169}$

Two commentators, Cawthorne and Scott-both lecturers at the University of Sydney-have noted: "[P]olitical interference in public health is not helpful as a general rule, but political posturing in these types of events is particularly unhelpful. It breeds unwarranted fear and drowns out more important

164. SteelFisher et al., supra note 155 , at 791.

165. See Who Will Ebola Hurt in the Midterm Elections?, CBS News (Oct. 21, 2014, 6:56 $\mathrm{AM}$ ), http://www.cbsnews.com/news/ebola-outbreak-midterm-election-candidates-using-crisis-indebate/[https://perma.cc/A4V5-LEZM] ("In recent weeks, candidates across the political spectrum have tried to use the public's fear of Ebola to their advantage.").

166. Siddons, supra note 157.

167. Colin Campbell, Obama Attacks Critics of His Response to Ebola, Bus. INSIDER (Oct. 29, 2014, 4:58 PM), http://www.businessinsider.com/obama-attacks-critics-of-his-response-toebola-2014-10 [https://perma.cc/MAV9-2JSP].

168. Lisa Rosenbaum, Communicating Uncertainty —Ebola, Public Health, and the Scientific Process, 372 New Eng. J. Med. 7, 7 (2015).

169. Craig Spencer, Having and Fighting Ebola-Public Health Lessons from a Clinician Turned Patient, 372 New Eng. J. MeD. 1089, 1091 (2015). 
messages."170

For example, regarding the outbreak, "Once it became clear that a serious emergency was under way in West Africa, many local clinicians should have been recruited, and trained personnel should have flowed rapidly into the affected countries. That didn't happen."171

Rather, the threat of detention and mandatory quarantine measures instituted by Governors Andrew Cuomo of New York and Chris Christie of New Jersey may have deterred public health workers from volunteering. ${ }^{172}$ On the other hand, the Obama administration's negative response to these state quarantine measures may not have been entirely driven by public health reasons. It is possible, indeed likely, that the administration's response to the Ebola crisis was also a political move, i.e., not wanting to stigmatize people of African origins; not wanting to affect trade relations between West Africa and the U.S., and thus giving leverage to China in that region; and not wanting to impair airlines in their business, particularly those American airlines that partner with European carriers to fly to West Africa. If true, then both sides were using public health for non-public health purposes, and as is often the case, the loser in this ping pong game is the public health community, which is blamed by both sides. Put succinctly, "public health officials are criticized for crying wolf or overreacting if threats fail to appear (perhaps because they were prevented) and for falling down on the job if threats do in fact materialize."173

To be sure, the 2014 Ebola pandemic is only one of several examples where a disease or health crisis has been used for political purposes here in the U.S. ${ }^{174}$ An identical response occurred during the HIV/AIDS epidemic in the early 1980s to mid 1990s. The response to HIV/AIDS is probably the most salient example of how intertwined politics, policy, and public health care is. ${ }^{175}$ In 1987 , then-

170. Grant Hill-Cawthorne \& Adam Kamradt-Scott, Mandatory Ebola Quarantine Is About Politics, Not Public Health, CONVERSATION (Oct. 28, 2014, 3:07 PM), http://theconversation. com/mandatory-ebola-quarantine-is-about-politics-not-public-health-33531 [https://perma.cc/D9KF-S5C6].

171. Bill Gates, The Next Epidemic-Lessons from Ebola, 375 NEw ENG. J. MED. 1381, 1382 (2015).

172. Id.; Ebola Fight, Time (Oct. 26, 2014), http://time.com/3539946/ebola-anthony-faucichris-christie/ [https://perma.cc/VL86-U877] (noting that "mandatory quarantines for health workers returning from treating Ebola in West African countries won't help stop the spread of disease" because it discourages volunteers); Thompson, supra note 160 (noting "Dr. Anthony Fauci, director of the U.S. National Institute of Allergy and Infectious Diseases, said Sunday that he did not favor such a quarantine because it could discourage health workers from going to West Africa to help battle the Ebola outbreak ....").

173. Brown, supra note 3, at 164-65.

174. See Julie Percha, Who is Fueling Ebola Fears? Politicians, of Course, WAsh. Post (Oct. 16, 2014), https://www.washingtonpost.com/news/the-fix/wp/2014/10/16/whos-fueling-ebola-fearspoliticians-of-course-video/ [https://perma.cc/FL86-64Y8] (explaining "When it comes to political attacks just before an election, nothing is off-limits. Including, apparently, a deadly disease.").

175. Peter Piot et al., Good Politics, Bad Politics: The Experience of AIDS, 97 AM. J. PuB. 
Senator Jesse Helms (R-N.C.), offered an amendment to the appropriations bill for the Departments of Labor, Health and Human Services, and Education, prohibiting the "Centers for Disease Control from funding AIDS programs that promote, encourage or condone homosexual activities." 176 Senator Helms reportedly referred to HIV and AIDS victims as "perverts." 177 Thus, animus towards a certain segment of the population (homosexuals) was turned into lousy public health policy by Congress. ${ }^{178}$ Similarly, the Ebola virus disease outbreak is an example of partisan politics, if less dramatic, being turned into lousy public health policy by some governors.

But perhaps the most striking contemporary example of turning public health issues into all things politics, with significant damage to public health practice, ${ }^{179}$ is the passage, implementation, and subsequent legal and policy battles of the 2010 Patient Protection and Affordable Care Act.

\section{THE AFFordable CARE ACT}

In 2010, Congress passed the Patient Protection and Affordable Care Act ("ACA") ${ }^{180}$ As a center piece of the ACA, the law focused on preventive services in health, ${ }^{181}$ i.e., the Act contains significant public health provisions, focusing on promoting the availability of prevention and wellness services. ${ }^{182}$ Two features of the ACA have generated the most controversy and led to two landmark Supreme Court cases. ${ }^{183}$ The first is the individual mandate ${ }^{184}$ and the second is

HeALth 1934, 1934 (2007).

176. Edward I. Koch, Senator Helms's Callousness Toward AIDS Victims, N.Y. TimES (Nov. 7, 1987), http://www.nytimes.com/1987/11/07/opinion/senator-helms-s-callousness-toward-aidsvictims.html [https://perma.cc/KDK3-WTW9].

177. Id. Senator Helms reportedly said, "We have got to call a spade a spade, and a perverted human being a perverted human being." Id. Interestingly, in 2002, at a Christian Conference on HIV/AIDS convened by Franklin Graham, son of evangelist Billy Graham in South Carolina, Senator Helms reportedly stated that "'I'm so ashamed that I have done so little' to help the victims of AIDS in Africa." Holly Burkhalter, The Politics of AIDS: Engaging Conservative Activists, FOREIGN AFF. (Jan./Feb. 2004), https://www.foreignaffairs.com/articles/2004-01-01/politics-aidsengaging-conservative-activists [https://perma.cc/8UB3-C4AM].

178. Koch, supra note 176.

179. See David Blumenthal et al., The Affordable Care Act at 5 Years, 372 New Eng. J. Med. 2451, 2455 (2015) (stating "The heated political debate over the ACA and the lack of definitive evaluations for so many of its numerous programs further complicate efforts to assess its track record at the 5-year point.").

180. Affordable Care Act, Pub. L. No. 111-148, 124 Stat. 119 (2010).

181. Christopher Ogolla, Public Health Implications of Religious Exemptions: A Balance Between Public Safety and Personal Choice, or Religion Gone Too Far?, 25 HeAlth Matrix 257, 286 (2015).

182. John Aloysius Cogan Jr., The Affordable Care Act's Preventive Services Mandate: Breaking Down the Barriers to Nationwide Access to Preventive Services, 39 J. L. MED. \& ETHICS 355, 355 (2011).

183. Burwell v. Hobby Lobby Stores, Inc., 134 S. Ct. 2751 (2014); National Fed'n of Indep. 
the contraception mandate. ${ }^{185}$

\section{A. The Individual Mandate}

1. Background.-No provision of the Affordable Care Act has been more contentious than the so-called "individual mandate," 186 the constitutionality of which was upheld by the Supreme Court in National Federation of Independent Business v. Sebelius. ${ }^{187}$ There, plaintiffs and twenty-six states alleged, among other things, that the individual mandate ${ }^{188}$ provisions of the ACA exceeded Congress's powers under Article I of the Constitution. ${ }^{189}$ "The legal challenges assert that Congress lacks authority pursuant to the Commerce Clause and the Necessary and Proper Clause to compel individuals to purchase health insurance." ${ }^{, 190}$ After there was a circuit split between the Sixth Circuit, which upheld the mandate, and the Eleventh Circuit, which found the mandate unconstitutional, the Supreme Court granted certiorari and held that the mandate could not be sustained under the Commerce Clause but was a valid exercise of the taxing power under the Constitution. ${ }^{191}$ Chief Justice Roberts, writing for the majority, observed that "[T]he Affordable Care Act's requirement that certain individuals pay a financial penalty for not obtaining health insurance may reasonably be characterized as a tax. Because the Constitution permits such a tax, it is not our role to forbid it, or to pass upon its wisdom or fairness." 192 Despite the Supreme Court's ruling, other plaintiffs have subsequently filed suit in federal court challenging various components of the Affordable Care Act, including the individual mandate. ${ }^{193}$

Bus. v. Sebelius, 132 S. Ct. 2566 (2012).

184. National Federation of Independent Business, 132 S. Ct. at 2580 (noting twenty-six states challenged the Constitutionality of the individual mandate).

185. Hobby Lobby, 132 S. Ct. at 2759-60 (holding the HHS contraceptive mandate to be illegal).

186. Wendy E. Parmet, The Individual Mandate: Implications for Public Health Law, $39 \mathrm{~J}$. L. MeD. \& ETHICS 401, 401 (2011).

187. Hobby Lobby, 132 S. Ct. at 2608.

188. The individual mandate requires "most individuals to maintain health insurance or potentially pay a penalty for non-compliance. Specifically, most individuals are required to maintain minimum essential coverage for themselves and their dependents." See ANNIE L. MACH, Cong. Research Serv., R41331, Individual Mandate Under The ACA 1 (2015).

189. National Federation of Independent Business, 132 S. Ct. at 2580.

190. Peter J. Smith, Federalism, Lochner, and the Individual Mandate, 91 B.U. L. REV., 1723, 1723 (2011).

191. National Federation of Independent Business, 132 S. Ct. at 2580-81, 2608.

192. Id. at 2600 .

193. See Hotze v. Burwell, 784 F.3d 984 (5th Cir. 2015); see also Hotze v. Sebelius, 991 F. Supp. 2d 864, 886 (S.D. Tex. 2014), vacated \& remanded, Hotze, 784 F.3d 984 (stating "[S]triking down either the individual mandate or the employer mandate as unconstitutional under the Takings Clause would fly in the face of the Supreme Court's decision in NFIB. As noted, the Supreme Court concluded that the individual mandate was constitutional under Congress's taxing power. For the 
2. Misuse of the Individual Mandate.-The mandate has been used for nonpublic health purposes both by its proponents and opponents alike. Although it has been argued that critics of the mandate are driven by their animus towards President Obama, ${ }^{194}$ it is equally true that some supporters and opponents of the individual mandate are driven more by political opportunism ${ }^{195}$ and party ideology than by public health principles. For example, in the 2008 Democratic Primary, "it was then-Senator Obama who attacked [the mandate] and used it to distinguish his approach from then-Senator Clinton's plan. Obama decried the individual mandate because he was convinced that people wanted insurance and government would not have to coerce them into it." 196 After the 2008 general election, Obama changed his mind and supported the mandate. ${ }^{197}$

Among its critics, the mandate has served as a catalyst for attacks on big government. ${ }^{198}$ Opponents "[view] the 'mandate' as a lightning rod to stoke federalist and public fears of a federal intrusion into every aspect of our personal lives that would ultimately destroy civilization as we know it." 199 For example, a senior fellow at the Heritage Foundation, a conservative Washington, D.C. think tank, states that the individual mandate is "an unconstitutional violation of personal liberty and strikes at the heart of American federalism." ${ }^{200}$ Similar

reasons set forth above, the employer mandate also is constitutional.").

194. As of January 2015, the House of Representatives had voted sixty-two times to repeal the Affordable Care Act, including the individual mandate. See Jennifer Steinhauer, House Votes to Send Bill to Repeal Health Law to Obama's Desk, N.Y. Times (Jan. 6, 2016), http://www.nytimes. com/2016/01/07/us/politics/house-votes-to-send-bill-to-repeal-health-law-to-obamasdesk.html?_r=0 [https://perma.cc/3W8E-D7NJ]. On March 24, 2017, "House Republican leaders, facing a revolt among conservatives and moderates in their ranks, pulled legislation to repeal the Affordable Care Act from consideration on the House floor." See Robert Pear et al., In a Major Defeat for Trump, Push to Repeal Health Law Fails, N.Y. Times (Mar. 24, 2017), https://www. nytimes.com/2017/03/24/us/politics/health-care-affordable-care-act.html?_r=0 [https://perma.cc/6PPL-HVVP]; see also Samuel Metz, Obamacare a Successful Failure, Physicians for A NAT'L Health Program (Oct. 31, 2014), http://www.pnhp.org/news/2014/ october/obamacare-a-successful-failure [https://perma.cc/P3G7-5ZM6] (asking "Is the Affordable Care Act a failure? For some of us, the answer is simple: If you voted for President Obama, it must be a success. If you voted against the president, it must be a failure.").

195. See Parmet, supra note 186, at 403 (noting "many state officials (especially Republican officeholders) not only question the mandate's constitutionality but also believe that opposition to it is good politics").

196. Brietta Clark, A Moral Mandate \& the Meaning of Choice: Conceiving the Affordable Care Act After NFIB, 6 St. Louis U. J. Health L. \& Pol’y 267, 273 (2013).

197. Id.

198. $I d$. at 268.

199. Id. at 275 .

200. Robert E. Moffit, Obamacare and the Individual Mandate: Violating Personal Liberty and Federalism, HeRITAGE Found. (Jan. 18, 2011), http://www.heritage.org/research/reports/ 2011/01/obamacare-and-the-individual-mandate-violating-personal-liberty-and-federalism [https://perma.cc/S96H-Y94L]. 
arguments were made by the States. For example, "Between 2010 and 2016, at least 22 state legislatures had enacted laws and measures related to challenging or opting out of broad health reforms related to mandatory provisions of the [Act]."201

In February 2011, several members of the South Dakota House of Representatives introduced legislation to require all residents over the age of twenty-one to purchase a firearm. Representative Hal Wick, one of the bill's sponsors, explained that he did not actually want the legislature to adopt the proposal; instead, the proposal was a form of public protest, meant to draw attention to what he perceived as the unconstitutionality of the provision in the federal Patient Protection and Affordable Care Act ("ACA" or "the Act") that requires individuals to obtain health insurance. ${ }^{202}$

The individual mandate is important to public health because it is designed to reduce the number of uninsured Americans. ${ }^{203}$ Studies show that the mandate will "lower premiums for people buying insurance in the individual and smallgroup markets, and reduce the government's cost of subsidizing coverage for newly insured individuals. ${ }^{204}$ Supporters of the mandate have argued that

at its core, [the Affordable Care Act] is a public health act. As such, the individual mandate provision is designed not so much to regulate health care consumers' purchasing choices as it is to remedy a lack of universal access to basic health services, one of the leading causes of morbidity and mortality in the United States. ${ }^{205}$

The mandate seeks to prevent significant adverse selection leading to the erosion of insurance markets by "inducing healthy individuals to purchase insurance, thereby 'broaden[ing] the health insurance risk pool' and lowering costs. $" 206$

One compelling argument in support of the individual mandate has been that "at the state level, individual mandates are a relatively common staple of public health law." ${ }^{207}$ Some of the relatively common state mandates include but are not

201. Richard Cauchi, State Laws and Actions Challenging Certain Health Reforms, NAT'L Conf. St. Legislatures (Dec. 4, 2016) http://www.ncsl.org/research/health/state-laws-andactions-challenging-ppaca.aspx [https://perma.cc/V5MP-LHU4].

202. Smith, supra note 190, at 1723.

203. See What Are The Effects of the Individual Mandate?, RoBERT WoOd JoHnson Found. (Jan. 2012), http://www.rwjf.org/en/library/research/2012/01/what-are-the-effects-of-theindividual-mandate-.html [https://perma.cc/2LTT-MGMB].

204. $I d$.

205. James Hodge, Jr. et al., Congress, Courts, and Commerce: Upholding the Individual Mandate to Protect the Public's Health, 39 J.L. Med. \& ETHICs 394, 394 (2011).

206. Parmet, supra note 186, at 403 (quoting 42 U.S.C. $§ 18091(2)(I)(2012)$ ).

207. Id. at 404 . 
limited to: motorcycle helmet legislation, ${ }^{208}$ mandatory school vaccine requirements, ${ }^{209}$ mandatory seatbelt laws, ${ }^{210}$ mandatory chlorination of drinking water, ${ }^{211}$ and mandatory car insurance. ${ }^{212}$ Therefore to contend that the individual mandate is a federal takeover of healthcare is as convincing as it is seismic. But as the discussion below on the ACA's contraception mandate shows, others still have profound philosophical objections to federal initiatives in health, ${ }^{213}$ even if such programs are a relatively common staple of public health law in the individual states. For example, "today's preoccupation with the 'obesity epidemic' likewise raises questions about how far governments should go toward influencing how much citizens weigh, what they eat, and how often they exercise." ${ }^{214}$ How much then, should government influence women's health, specifically, contraception?

\section{B. The Contraception Mandate}

"Contraception plays a significant role in women's health and public health in general. It is vital to preventing unintended pregnancies, which account for half of all pregnancies among American women." ${ }^{215}$ As described above, Congress passed the ACA in 2010. The ACA required in pertinent part, that "[a] group health plan and a health insurance issuer offering group or individual health insurance coverage shall, at a minimum provide coverage for and shall not impose any cost sharing requirements ... with respect to women, such additional preventive care and screenings ... as provided for in comprehensive guidelines supported by the Health Resources and Services Administration."216 Therefore under the ACA, "large employers, except for religious organizations, must provide employees with health insurance coverage, including health care related to reproduction, from birth-control pills to pregnancy screening." ${ }^{217}$ This became popularly known as the Contraception Mandate. ${ }^{218}$ The Mandate has spawned numerous court challenges. ${ }^{219}$ For example, one commentator notes that after a

208. Id.

209. Id.

210. Id.

211. See, e.g., Brynn Grimley, State Orders Fircrest to Chlorinate Water by March, NEws TRIB. (Dec. 17, 2015), http://www.thenewstribune.com/news/local/article50326485.html [https://perma.cc/PXN8-WHDT] (describing that Washington state ordered residents of a local town to begin to chlorinate their water in the wake of growing water quality concerns).

212. Parmet, supra note 186, at 409.

213. Blumenthal et al., supra note 179, at 2457.

214. Brown, supra note 3, at 162.

215. Ogolla, supra note 181 , at 275.

216. 42 U.S.C. § 300gg-13(a) (2012).

217. Seema Mohapatra, Time to Lift the Veil of Inequality in Health-Care Coverage: Using Corporate Law to Defend the Affordable Care Act, 50 WAKE ForEST L. REV. 137, 137 (2015).

218. See generally id.

219. See, e.g., Burwell v. Hobby Lobby Stores, Inc., 134 S. Ct. 2751 (2014); Little Sisters of the Poor Home for the Aged v. Burwell, 794 F.3d 1151 (10th Cir. 2015), vacated and remanded 
few groups made claims that their religious liberty had been violated by the mandate "the number of Contraception Mandate challengers quickly grew, creating one of the largest religious liberty challenges in American history and triggering an equally outsized explosion of scholarly and popular commentary." 220 In the wake of these mostly religious-based challenges, to some, the contraception mandate has morphed from a public health issue to a religious, government infringement, individual liberty, equal protection, or discrimination cause of action. $^{221}$

After the Supreme Court ruled in Hobby Lobby Stores, Inc. that the contraception mandate violated the Religious Freedom Restoration Act of 1993 (RFRA), ${ }^{222}$ the Obama administration proposed a rule extending the accommodation to not-for-profit corporations. ${ }^{223}$ The accommodations were already provided to religious groups and charities in the form of contraception opt out. ${ }^{224}$ Predictably, several religiously affiliated nonprofits have sought to opt out of both the Mandate and its accommodations. ${ }^{225}$ In November 2015, the Court

for settlement discussions sub nom. Zubik v. Burwell, 136 S. Ct. 1557 (2016); Priests for Life v. U.S. Dep't of Health \& Human Servs., 772 F.3d 229 (D.C. Cir. 2014), vacated and remanded for settlement discussions sub nom. Zubik, 136 S. Ct. 1557; Catholic Health Care Sys. v. Burwell, 796 F.3d 207 (2d Cir. 2015), vacated and remanded for reconsideration in light of Zubik, $136 \mathrm{~S}$. Ct. 2450 (2016); Geneva Coll. v. Sec'y U.S. Dep't of Health \& Human Servs., 778 F.3d 422 (3d Cir. 2015), vacated and remanded for settlement discussions sub nom. Zubik, 136 S. Ct. 1557; E. Tex. Baptist Univ. v. Burwell, 793 F.3d 449 (5th Cir. 2015), vacated and remanded for settlement discussions sub nom. Zubik, 136 S. Ct. 1557; Mich. Catholic Conference \& Catholic Family Servs. v. Burwell, 807 F.3d 738 (6th Cir. 2015), vacated and remanded for reconsideration in light of Zubik, 136 S. Ct. 2450 (2016); Univ. of Notre Dame v. Burwell, 786 F.3d 606 (7th Cir. 2015), vacated and remanded for reconsideration in light of Zubik, 136 S. Ct. 2007 (2016); Wheaton Coll. v. Burwell, 791 F.3d 792 (7th Cir. 2015); Grace Schs. v. Burwell, 801 F.3d 788 (7th Cir. 2015), vacated and remanded for reconsideration in light of Zubik, 136 S. Ct. 2011 (2016); Dordt Coll. v. Burwell, 801 F.3d 946 (8th Cir. 2015), vacated and remanded for reconsideration in light of Zubik, 136 S. Ct. 2006 (2016); Sharpe Holdings, Inc. v. U.S. Dep't of Health \& Human Servs., 801 F.3d 927 (8th Cir. 2015), vacated and remanded on other grounds sub nom. U.S. Dep't of Health \& Human Servs. v. CNS Int'1 Ministries, 136 S. Ct. 2006 (2016).

220. Zoe Robinson, The Contraception Mandate and the Forgotten Constitutional Question, 2014 Wis. L. REV. 749, 750 (2014).

221. Erik Eckholm, Both Sides Eager to Take Birth Control Coverage Issue to Voters, N.Y. TiMES (Feb. 15, 2012), http://www.nytimes.com/2012/02/16/us/politics/both-sides-eager-to-takecontraception-mandate-debate-to-voters.html [https://perma.cc/CHZ4-UG7B].

222. 42 U.S.C. $\S 2000$ bb-1 to -4 (2012).

223. Kimberly Leonard, After Hobby Lobby, a Way to Cover Birth Control, U.S. News (July 10, 2015, 5:35 PM), http://www.usnews.com/news/articles/2015/07/10/after-hobby-lobby-rulinghhs-announces-birth-control-workaround [https://perma.cc/XH2C-3PVM].

224. Id.

225. Of the Courts of Appeal cases listed in supra note 219, only the 8th Circuit Court of Appeals in Dordt College and Sharpe Holdings found the contraception opt out accommodation unconstitutional leading to the circuit split. Because the Supreme Court reversed the lower courts 
granted certiorari to seven appellate court cases (petitioners) challenging the contraception mandate opt out. ${ }^{226}$ The legal question presented is "[w]hether RFRA entitles petitioners not only to opt out of providing contraceptive coverage themselves, but also to prevent the government from arranging for third parties to provide separate coverage to the affected women."227

1. The U.S. Supreme Court Decides Not to Decide.-On May 16, 2016 the U.S. Supreme Court, in a per curiam opinion, vacated the appellate decisions against the petitioners and remanded to the lower courts. ${ }^{228}$ In its brief opinion, the Court stated, in pertinent part, as follows:

Following oral argument, the Court requested supplemental briefing from the parties addressing whether contraceptive coverage could be provided to petitioners' employees, through petitioners' insurance companies, without any such notice from petitioners... .

In light of the positions asserted by the parties in their supplemental briefs, the Court vacates the judgments below and remands to the respective United States Courts of Appeals for the Third, Fifth, Tenth, and D.C. Circuits. Given the gravity of the dispute and the substantial clarification and refinement in the positions of the parties, the parties on remand should be afforded an opportunity to arrive at an approach going forward that accommodates petitioners' religious exercise while at the same time ensuring that women covered by petitioners' health plans receive full and equal health coverage, including contraceptive coverage. ${ }^{229}$

This very short opinion has been described variously as "punting,", ${ }^{230}$ or "peculiar and seemingly unprecedented."231 Indeed the Court decided not to decide by noting that "the Court expresses no view on the merits of the cases. In particular, the Court does not decide whether petitioners' religious exercise has

in Zubik, those decisions are no longer the law.

226. See Zubik, v. Burwell, 136 S. Ct. 1557 (2016).

227. See Brief for the Respondents in Opposition at I, Zubik v. Burwell, 136 S. Ct. 1557 (2016) (Nos. 14-1418 \& 15-191), https:/www.justice.gov/sites/default/files/osg/briefs/2015/09/ 11/14-1418_15-191_zubik_geneva_college_v_burwell_2015-08-19_-_final.pdf[https://perma.cc/ YSR3-NCSP].

228. Zubik, 136 S. Ct. at 1560.

229. Id. at 1559 (internal citations and quotations omitted).

230. Caroline Mala Corbine, Symposium, Punting of Substantial Religious Burden, The Supreme Court Provides No Guidance for Future RFRA Challenges to Anti-Discrimination Law (May 17, 2016), http://www.scotusblog.com/2016/05/symposium-punting-on-substantial-religiousburden-the-supreme-court-provides-no-guidance-for-future-rfra-challenges-to-anti-discriminationlaws-2/ [https://perma.cc/4HXH-LQBV].

231. Eugene Volokh, Prof. Michael McConnell on Zubik v. Burwell, WASH. Post. (May 17, 2016), https:/www.washingtonpost.com/news/volokh-conspiracy/wp/2016/05/17/prof-michaelmcconnell-on-zubik-v-burwell-yesterdays-supreme-court-rfra-contraceptive-decision/ [https://perma.cc/C6UC-EJS8] 
been substantially burdened, whether the Government has a compelling interest, or whether the current regulations are the least restrictive means of serving that interest." 232

So what is public health to make of this decision? The jury is still out on this one, since the decision can be read as a tie even if the Court was trying to avoid the result. ${ }^{233}$ Nevertheless, one sentence in the decision offers a glimmer of hope for public health practitioners. It states that "[n]othing in this opinion, or in the opinions or orders of the courts below, is to affect the ability of the Government to ensure that women covered by petitioners' health plans 'obtain, without cost, the full range of FDA approved contraceptives." ${ }^{234}$ This view was endorsed by Justice Sotomayor's concurrence, joined by Justice Ginsburg. ${ }^{235}$

2. Implications for Public Health Practice.-The use of ACA's individual and contraceptive mandates for non-public health purposes has had significant impacts on public health practice, most of which have little to do with core purposes of public health. ${ }^{236}$ First, as mentioned previously, the ACA became pivotal in the national elections from 2010 to $2014 .{ }^{237}$ So much money in political advertisements was spent against the ACA that it became among the most polarizing and political issues in the country. ${ }^{238}$ This has had a negative impact on public health by diverting attention from access to healthcare for the enrollees, ${ }^{239}$ to what are essentially non-public health purposes. ${ }^{240}$ It is likely

232. Zubik, 136 S. Ct. at 1560.

233. Some commentators have opined that the Court was unable to muster a five-justice majority and wanted to avoid a four-to-four split. See Corbine, supra note 230 (noting that "almost certainly because it was unable to muster a five-Justice majority, and wanted to avoid another fourto-four split, the Supreme Court avoided answering Zubik's central question"); Adam Liptak, Justices, Seeking Compromise, Return Contraceptive Cases to Lower Courts, N.Y. Times (May 16, 2016), http://www.nytimes.com/2016/05/17/us/supreme-court-contraception-religious-groups.html [https://perma.cc/BF3E-6BXF] (describing "the opinion is the latest indication that the Supreme Court, which currently has eight members, is exploring every avenue to avoid 4-to-4 deadlocks, even if it does not decide the question the justices have agreed to address").

234. Zubik, 136 S. Ct. at 1560-61 (quoting Wheaton College v. Burwell, 134 S. Ct. 2806, 2807 (2014)).

235. Id. at 1561 (Sotomayor, J., concurring).

236. According to the Centers for Disease Control and Prevention, the purposes of public health include: preventing epidemics and spread of disease, protecting against environmental hazards, preventing injuries, promoting and encouraging healthy behaviors, responding to disasters and assisting communities in recovery, and assuring the quality and accessibility of services. See Ctrs. For Disease Control and Prevention, The Ten Essential Public Health Services, (Mar. 2014), http://www.cdc.gov/nphpsp/documents/essential-phs.pdf [https://perma.cc/E2JP-LUNU].

237. See Aaron, supra note 43 (discussing the importance of the congressional election on the implementation of the ACA); Blendon \& Benson, supra note 43 (exploring the impact of the ACA on the 2014 congressional elections).

238. Blendon \& Benson, supra note 43, at e31(3), e31(6).

239. As of February 2015, an estimated 11.7 million people had enrolled into a 2015 health insurance plan through the ACA's Health Insurance Marketplace. See DeP'T OF HEALTH \& Human 
possible, for example, that many people who would otherwise qualify for the health insurance, would choose not to enroll either because of partisan ideology or stigma associated with the Act. ${ }^{241}$

Second, the national debate on the contentious issues of the Act, the Individual Mandate, ${ }^{242}$ the Contraception Mandate, ${ }^{243}$ and the creation of state and federal "exchanges" 244 have tended to overshadow the core public health aspects of the law, like its emphasis on disease prevention. For example, "Many of the 10 major titles in the law, especially Title IV, Prevention of Chronic Diseases and Improving Public Health, advance a prevention theme through a wide array of new initiatives and funding." ${ }^{245}$ So much political capital has been spent on the more controversial aspects of the ACA that the more positive and bipartisan ${ }^{246}$ aspects of the Act have been overshadowed. For example, the ACA requires evidence-based preventive services to be covered without cost sharing, yet opponents have conflated the no cost sharing requirement with mostly

Servis., Health Insurance Marketplaces 2015 Open Enrollment Period: March ENROLLMENT REPORT (Mar. 10, 2015), https://aspe.hhs.gov/sites/default/files/pdf/83656/ ib_2015mar_enrollment.pdf[https://perma.cc/KUK7-N5EF]. Additionally, in September 2015, the U.S. Census Bureau reported that the number of people without health insurance dropped in 2014 by 8.8 million, from 41.8 million to a total of 33 million. See JessiCA C. SMith \& CARLA Medalia, U.S. Census Bureau, Health Insurance Coverage in the United States: 2014, at 3 (Sept. 2015), https://www.census.gov/content/dam/Census/library/ publications/2015/demo/p60-253.pdf [https://perma.cc/VC6W-JK8Y]. For the January 2016 open enrollment period (OEP), "nearly 11.3 million individuals selected or were automatically reenrolled in Marketplace plans during the first eight weeks of the 2016 OEP.” See Dep't of Health \& Human Servs., Health Insurance MarketPlaces 2016 Open EnRollment Period: January Enrollment Report (Jan. 7, 2016), https://aspe.hhs.gov/sites/default/files/pdf/167981/MarketPlaceEnrollJan2016.pdf [https://perma.cc/M2CM-VLM7].

240. See generally Gitterman \& Scott, supra note 45, at 555 .

241. See generally Teresa Toguchi Swartz et al., Welfare and Citizenship: The Effects of Government Assistance on Young Adults' Civic Participation, 50 Soc. Q. 633, 634 (2009) (investigating the relationship between the welfare state and civic engagement and observing that some empirical evidence suggests that stigmatizing programs such as welfare are thought to have deleterious effects on civic participation, while programs that valorize citizenship, such as veteran's benefits or Social Security, are thought to have mobilizing effects).

242. See generally National Fed'n of Indep. Bus. v. Sebelius, 132 S. Ct. 2566 (2012) (upholding the constitutionality of the individual mandate).

243. See generally Hobby Lobby v. Burwell, 134 S. Ct. 2751 (2014) (declining to decide if the Contraception Mandate violated the religious liberties of certain employers).

244. See generally King v. Burwell, 135 S. Ct. 2480 (2015) (explaining how a federal exchange is an exchange under the statute).

245. Howard K. Koh \& Kathleen G. Sebelius, Promoting Prevention Through the Affordable Care Act, 363 NEw Eng. J. MED. 1296, 1296 (2010).

246. The word bipartisan is used here for those aspects of the law that are popular and garner a majority in public opinion polls, for example, the ban on pre-existing conditions and allowing dependents to stay on their parents' health insurance plans until age twenty-six. 
contraception, leading to court challenges on religious liberty grounds. ${ }^{247}$ It shouldn't be so.

Numerous provisions within the [ACA] are focused on reducing the nation's underlying burden of disease through enhanced prevention. Many of these provisions seek to increase patients' access to certain clinical preventive services commonly offered by health care providers (like immunizations) by improving coverage for these services under Medicaid, Medicare, and new private health plans. Other provisions (such as the creation of the Prevention and Public Health Fund; the establishment of the National Prevention, Health Promotion, and Public Health Council; and the creation of Community Transformation Grants) promise to dramatically expand federal engagement in and support for population-based interventions designed to facilitate healthy behaviors and environments. ${ }^{248}$

Nonetheless, these public health provisions are rarely mentioned in the public debate about the ACA.

This is not to say, however, that this Article is a blanket endorsement of the ACA or the government's position. Rather, the focus is on the manipulation of public health issues for other purposes, such as, winning or losing elections or challenging religious freedom rights. To be sure, there are several shortcomings as well as valid criticisms of the ACA. For example, "millions of Americans are still uninsured and even for those with coverage, substantial barriers remain to obtaining affordable, high-quality care." ${ }^{249}$ The Act has ushered in an era of complex new health insurance products featuring legions of out-of-pocket coinsurance fees, high deductibles, and narrow provider networks; ${ }^{250}$ therefore, one can advance the argument that the ACA's effectiveness is severely undercut by its massive bureaucracy.

Perhaps the most scathing criticisms of the ACA come from the dissents in both National Federation of Independent Business v. Sebelius ${ }^{251}$ and King v. Burwell. ${ }^{252}$ In those dissents, the minority opinions note that the Act exceeds federal power both in mandating the purchase of health insurance and in

247. See generally Zubik v. Burwell, 136 S. Ct. 1557 (2016).

248. See Eileen Salinsky, Nat'L Health Policy Forum, Governmental Public Health: An Overview of State and Local Public Health Agencies 3 (Aug. 18, 2010), https://www.nhpf.org/library/background-papers/BP77_GovPublicHealth_08-18-2010.pdf [https://perma.cc/ZJE8-7DQZ].

249. Benjamin D. Sommers, Health Care Reform's Unfinished Work-Remaining Barriers to Coverage and Access, 373 New Eng. J. Med. 2395, 2395 (2015).

250. Elisabeth Rosenthal, Insured, but Not Covered, N.Y. Times (Feb. 7, 2015), https://www.nytimes.com/2015/02/08/sunday-review/insured-but-not-covered.html?_r=0 [https://perma.cc/BCV9-Z6EH].

251. 132 S. Ct. 2566, 2642 (2014) (Scalia, J., dissenting).

252. 135 S. Ct. 2480, 2496 (2015) (Scalia, J., dissenting). 
[537] denying nonconsenting states all Medicaid funding, ${ }^{253}$ and that when it comes to the ACA, "normal rules of interpretation seem always to yield to the overriding principle of the present Court: The Affordable Care Act must be saved." ${ }^{254}$ Of course, this last zinger by the late Justice Antonin Scalia-one among many-may not be a legitimate criticism of the Act or the Court, but it embodies the sharp partisan divisions that have embroiled the law from the very beginning. It is no wonder then that Act provides an example of using public health for non-public health purposes.

Finally, the U.S. Supreme Court's opinion in Zubik $k^{255}$ still leaves many questions unanswered. For example, the Court never answered the critical question of whether "filing paperwork in order to obtain a religious exemption from a law constitute[s] a substantial burden on religious liberty." 256 Additionally, because the Court remanded the case to the lower courts, ${ }^{257}$ it is likely that one of the cases may end up back at the Supreme Court again. This means that the battle over the ACA, or at least the Contraception Mandate, is far from over. Meanwhile, the public health community awaits with baited breath for the next misuse of the ACA provisions and the cloud of judicial uncertainty.

\section{Reception Within the Public Health Community and the Courts}

If the non-public health purposes result in harm to the population served, should the non-public health purposes warrant a more inhospitable reception (i.e., more evidential scrutiny and skepticism) within the public health community in general and courts in specific? The answer would seem to be unequivocally yes, for the following reasons. First, it is possible to argue that manipulation of public health for non-public health purposes is actually illegitimate use of public health. When people think of public health, they should generally think of it as benevolent, something of value, not a profession used to achieve sinister goals. Second, a Pew Research Center survey in November 2015 reported that seventyone percent of the public viewed the CDC - the premier public health agency in the nation-favorably, behind only the U.S. Postal Service and National Park Service. ${ }^{258}$ This is important because any manipulation of public health is likely to erode the public's trust in CDC. ${ }^{259}$ In times of public health emergencies, such

253. Nat'l Fed'n of Indep. Bus., 132 S. Ct. at 2643 (Scalia, J., dissenting).

254. King, 135 S. Ct. at 2497 (Scalia, J., dissenting).

255. 136 S. Ct. 1557 (2016).

256. Corbine, supra note 230.

257. Zubick, 136 S. Ct. at 1561.

258. Ratings of Federal Agencies, Congress and the Supreme Court, in Beyond Distrust: How Americans View Their Government, PEW RES. CTR. (Nov. 23, 2015), http://www.peoplepress.org/2015/11/23/4-ratings-of-federal-agencies-congress-and-the-supreme-court/ [https://perma.cc/44TF-T8RV].

259. See generally Abbigail Tumpey \& Nicole Coffin, Ctr. Disease Control AND Prevention, Keeping the Public's Trust: How to Communicate About NHSN Data and HAI Prevention, https://www.cdc.gov/nhsn/PDFs/training/training-keeingPublicTrust-bw.pdf [https://perma.cc/JM3P-LJ6B] (last visited Mar. 31, 2017). 
as Pandemic Influenza or the Ebola virus, it is critical that people trust messages coming from the federal agency entrusted with responding to the disaster. For example, "Risks generated by a trusted institution are better tolerated than risks that are generated by a mistrusted institution. Risks generated by a mistrusted institution will be perceived as greater than risks generated by a trusted institution." 260

Finally, courts should be inhospitable (evidentially) to cases where public health is being used for non-public health purposes. That's because "[p]olitical agendas that misrepresent facts risk the public's health. . . In the face of evidence suggesting a policy will harm the public's health, politicians should acknowledge the cost of the policy and, if they still support it, defend it on other grounds." ${ }^{261}$ Thus, courts are in a better position to ensure that when public health is misused, those who are injured get some sort of legal remedy. ${ }^{262}$ The cases discussed in the section below further illustrate this point.

\section{Remedies for Public Health Injuries}

In tort law a victim may have several reliefs including legal, e.g., damages, restitution, and punitive remedies. For public health injuries, however, relief for plaintiffs is mostly non-existent, or where available, severely limited. This is principally due to two reasons. First, the doctrine of standing precludes public health practitioners from any recovery for harm caused by use of public health for non-public health purposes. Under the standing doctrine "a plaintiff seeking to bring suit in federal court must demonstrate that he has suffered injury in fact, that the injury is fairly traceable to the actions of the defendant and that the injury will likely be redressed by a favorable decision." 263 It is unlikely that public health practitioners can clear this bar, since practitioners themselves are unlikely to suffer any injury in fact, other than to the reputation of their profession. So, for example, where politicians misuse public health for political grandstanding, as happened during the 2014 Ebola virus disease outbreak, no remedy would be available to public health practitioners.

Second, since public health is "what we as a society do collectively to assure the conditions in which people can be healthy, ${ }^{, 264}$ the primary providers of public

260. Crisis and Emergency Risk Communication: Pandemic Influenza, CTRS. FOR DiseASE Control AND PREvention 10 (Oct. 2007), http://emergency.cdc.gov/cerc/resources/pdf/cercpandemicflu-oct07.pdf [https://perma.cc/237P-S8L2].

261. Joshua M. Sharfstein, Rethinking Science and Politics, 94 Milbank Q. 39, 42 (2016), http://www.milbank.org/the-milbank-quarterly/search-archives/article/4076/rethinking-science-andpolitics [https://perma.cc/5JPH-EZ7B].

262. Some may argue, with force, that legislatures are better equipped to provide remedies for misuse of public health than courts of law. Point well taken. However, where the politicians are the ones misusing public health, as is often the case, what is the likelihood that they would provide a remedy for those harmed by their distortions?

263. U.S. CONST. art. III, § 2, cl. 1; see also F. Andrew Hessick, Standing, Injury in Fact, and Private Rights, 93 CORNELl L. ReV. 275, 276 (2008).

264. InST. OF MED., supra note 60. 
health services tend to be government public health agencies; consequently, because the government typically enforces violations of public rights, it is highly unlikely that the government itself would seek any remedies where the injury is caused by its officials or agencies. No government would likely want to expose its public officials to personal liability, hence the principle of sovereign immunity in many states.

Notwithstanding the aforementioned obstacles, victims of misuse of public health for non-public health purposes may, in some occasions, vindicate their private rights in courts. Three legal theories they can rely on are: (1) the Fifth and Fourteenth Amendments Due Process and Equal Protection Clauses; (2) statutory remedies; (3) and common law remedies.

\section{A. Fifth and Fourteenth Amendments Due Process and Equal Protection Clauses}

The Fifth and Fourteenth Amendment Due Process Clauses prohibit the government from depriving an individual of his or her "life, liberty, or property, without due process of the law."265 Additionally, the Fourteenth Amendment prohibits violating an individual's rights of due process and equal protection. ${ }^{266}$ Two cases below illustrate the vindication of private rights, based on the Due Process and Equal Protection Clauses, where public health is manipulated for non-public health purposes.

1. Jew Ho v. Williamson.-On March 6, 1900, a Chinese laborer was found dead in the basement of a hotel in San Francisco's Chinatown. ${ }^{267}$ An autopsy revealed the presence of the plague bacilli. ${ }^{268}$ As a result of this autopsy, the local board of health decided to quarantine all of Chinatown. ${ }^{269}$ Plaintiff, Jew Ho, was the owner of a grocery store who resided within the quarantined district. ${ }^{270}$ His complaint alleged that the quarantine was "enforced against persons of the Chinese race and nationality only, and not against persons of other races"; that all other "stores, residences, and other buildings within the quarantined district ... occupied by persons of races other than Chinese," were "not subjected to any of the restrictions or limitations provided for" in the ordinance; that "all physicians employed by Chinese residents" were excluded from the district while permission was given to other "physicians to enter and depart from all buildings occupied by persons of races other than Chinese within said quarantined district" and that there was never "any case of bubonic plague within the limits of said quarantined district, nor any germs or bacteria of bubonic plague." 271

265. U.S. CONST. amend. V; U.S. CONST. amend. XIV, § 1.

266. U.S. CONST. amend. XIV, § 1.

267. Thomas V. DiBacco, Unwelcome as the 1900-1904 Plague, Wash. Times (Oct. 30, 2014), http://www.washingtontimes.com/news/2014/oct/30/dibacco-unwelcome-as-the-plague/ [https://perma.cc/8H4L-CMBV].

268. Jew Ho v. Williamson, 103. F. 10, 24 (C.C.N.D. Cal. 1900).

269. Id.

270. Id. at 12 .

271. Id. at 13 . 
Plaintiff further contended that

he ha[d] never had [n]or contracted said bubonic plague; that he ha[d] never been at any time exposed to the danger of contracting it, and ha[d] never been in any locality where said bubonic plague, or any germs or bacteria thereof, [had] existed; that the action of the defendants in confining and imprisoning the complainant and other Chinese residents within the limits of said quarantined district [was] a purely arbitrary, unreasonable, unwarranted, wrongful, and oppressive interference with the personal liberty of the complainant and the said Chinese residents, and with their right to the pursuit of their lawful business; that said resolution providing for the said quarantine, and designating said quarantine district, [was] wholly unauthorized, invalid, and void, and contrary to the constitution and laws of the United States, and contrary to and in violation of the laws of the state of California. ${ }^{272}$

Relying on medical evidence in finding for Jew Ho, the district court noted that the quarantining of thousands of people within a few blocks, i.e. 10,000 people within ten or twelve blocks would not stem the spread of the disease. ${ }^{273}$ Rather, it would offer the bacteria the chance "to enlarge its sphere and increase its danger and its destructive force." 274 Additionally, the court found the ordinance was administered with an "evil eye and an unequal hand," 275 and, as such, it violated the Fourteenth Amendment. ${ }^{276}$

When the court's findings are considered alongside the prevailing race relations in California circa 1900, the conclusion that the quarantine was used to target Chinese immigrant groups inexorably follows. Quarantine, in particular, can be extremely discriminatory and oppressive. ${ }^{277}$ Historically, large groups of people have been quarantined for nothing other than their race. ${ }^{278} \mathrm{~W}$ ith regard to Jew Ho, the 1900-1905 campaign against the black plague in Chinatown racialized the disease and resulted in discriminatory public health activities. Professor Judith Leavitt Waltzer, writing about lessons from the same Plague, notes that:

Two cautions from the San Francisco experience are most telling. Public

272. Id. at 13-14.

273. Id. at 22 .

274. Id. at 22-23.

275. Id. at 23 .

276. Id. at 24 .

277. See generally Eleanor Klibanoff, Awful Moments in Quarantine History: Remember Typhoid Mary?, NPR (Oct. 31, 2014, 5:38 PM), http://www.npr.org/sections/goatsandsoda/2014/ 10/30/360120406/awful-moments-in-quarantine-history-remember-typhoid-mary [https://perma.cc/TWL7-DTL2] (offering a look at quarantine use-and abuse-over the ages).

278. See, e.g., Howard Markel, Book Review: Quarantine! East European Jewish Immigrants and the New York City Epidemics of 1892, 338 NEw ENG. J. MED. 1235 (1998) (generally outlining an instance where an outbreak of Typhus Fever in late Nineteenth Century New York was blamed on Jewish immigrants). 
health work failed when its campaign against plague racialized the disease and resulted in discriminatory public health activities, and it failed when the business community and the state government put economic and political interests above concern for peoples' lives. ${ }^{279}$

A century and fifteen years later, quarantine again was thrust into the public debate. But unlike the Chinatown order that concerned a whole group of people, this time it concerned one healthcare nurse from Maine named Kaci Hickox.

2. State of Maine v. Kaci Hickox.-On October 24, 2014, Kaci Hickox, a nurse who had been caring for Ebola patients while on assignment with Doctors Without Borders in Sierra Leone, was placed in quarantine at a New Jersey hospital upon her return to the U.S. ${ }^{280}$ This occurred despite the fact that Ms. Hickox was asymptomatic and had tested negative for Ebola. ${ }^{281}$ Three days later, Ms. Hickox was released from quarantine and went to her home in Maine. When she got home, state public health officials, under instructions from Maine governor Paul Le Page, ordered Ms. Hickox to self-quarantine. ${ }^{282}$ When she threatened to disobey the instructions, the Director of the Maine Center for Disease Control and Prevention filed a Verified Petition for Public Health Order ${ }^{283}$ (hereinafter "Petition") seeking mandatory quarantine of Ms. Hickox. ${ }^{284}$ The Petition alleged that Ms. Hickox was a public health threat because she remained at risk of being infected with Ebola. ${ }^{285}$ In rejecting the mandatory quarantine petition, Chief Judge Charles C. La Verdiere of the Maine District Court wrote in his ruling that " $[\mathrm{t}]$ he state has not met its burden at this time to prove by clear and convincing evidence that limiting [Kaci Hickox's] movements to the degree requested is necessary to protect other individuals from the dangers of infection. ${ }^{286}$ More telling, the judge included the following caveat in his order:

279. Leavitt, supra note 29.

280. Kaci Hickox, Her Story: UTA Grad Isolated at New Jersey Hospital in Ebola Quarantine, DALl. Morning News (Oct. 29, 2014, 9:48 AM), http://www.dallasnews.com/ebola/headlines/ 20141025-uta-grad-isolated-at-new-jersey-hospital-as-part-of-ebola-quarantine.ece [https://perma.cc/E2HJ-6T8P].

281. Josh Dawsey et al., Kaci Hickox, Nurse Under Ebola Quarantine Returns to Her Home in Maine, WALL ST.J.(Oct. 27, 2014), http://www.wsj.com/articles/nurse-being-held-under-ebolaquarantine-at-newark-hospital-will-be-discharged-1414418399 [https://perma.cc/7CCG-C6UC].

282. Id.

283. Verified Petition for Public Health Order at 1, Mayhew v. Hickox, No. CV-14-36 (Dist. Ct. Me.Oct. 30,2014), http://www.courts.maine.gov/news_reference/high_profile/hickox/verified_ petition_for_public_health_order.pdf[https://perma.cc/9DDX-ZESG]; see ME.REV.STAT. tit. 22, $\S 811$ (2016) on court procedures for filing a verified public health petition and ME. REV. STAT. tit. $22, \S 812$ (2016) on public health measures including the court's issuance of a mandatory order for treatment.

284. See Verified Petition for Public Health Order, supra note 283.

285. Id

286. See Order Pending Hearing at 3, Mayhew v. Kaci Hickox, No. CV-2014-36 (Dist. Ct. Me. Oct. 31, 2014), http://www.courts.maine.gov/news_reference/high_profile/hickox/order_pending hearing.pdf [https://perma.cc/SK9X-4HMP]. 
Respondent should understand that the court is fully aware of the misconceptions, misinformation, bad science and bad information being spread from shore to shore in our country with respect to Ebola. The court is fully aware that people are acting out of fear and that this fear is not entirely rational. However, whether that fear is rational or not, it is present and it is real. Respondent's actions at this point, as a health care professional, need to demonstrate her full understanding of human nature and the real fear that exist. She should guide herself accordingly. ${ }^{287}$

Whether viewed as a gentle rebuke of Ms. Hickox or just a friendly reminder, the judge's comments allude to a key fact, that the petition to quarantine Ms. Hickox was not based on public health necessity; rather, it was anchored on fear and bad science. ${ }^{288}$ One could add another reason for such measures, that is, politics stoked by the governors. ${ }^{289}$ The quarantine measures found little support in law. As an example, in the Petition, the Director alleged that Ms. Hickox constituted a public health threat within the meaning of 22 M.R.S. $\$ 801(10)$. But this statute defines a public health threat as follows: "Public health threat" means any condition or behavior that can reasonably be expected to place others at significant risk of exposure to a toxic agent or environmental hazard or infection with a notifiable disease or condition. ${ }^{290}$ It goes on to define conditions that pose public health threats as follows:

A. A condition poses a public health threat if an infectious or toxic agent or environmental hazard is present in the environment under circumstances that would place persons at significant risk of an adverse effect on a person's health from exposure to or infection with a notifiable disease or condition.

B. Behavior by an infected person poses a public health threat if: (1) the infected person engages in behavior that has been demonstrated

287. Id.

288. It is unnerving that the Chief Judge acknowledges the illegitimate use of public health by the state of Maine, but nevertheless recommends that a healthy Kaci Hickox act with due regards to the fear that existed at the time, because the fear was not entirely irrational. One can make the argument that Ms. Hickox would have been entitled to a torts remedy because the claim against her represented misuse of legal procedure. See Restatement (SECOnd) OF ToRTs § 682 (Am. LAw INST. 1977) (providing that "One who uses a legal process, whether criminal or civil, against another primarily to accomplish a purpose for which it is not designed, is subject to liability to the other for harm caused by the abuse of process"). However, it is unlikely here that she could prove an ulterior motive on the part of the state of Maine.

289. Jess Bibgood \& Kate Zernike, From Governors, A Mix of Hard-Line Acts and Conciliation over Ebola, N.Y.TIMES (Oct. 30, 2014), http://www.nytimes.com/2014/10/31/us/kacihickox-nurse-under-ebola-quarantine-takes-bike-ride-defying-maine-officials.html [https://perma.cc/CJ6J-LJK5].

290. Me. Rev. Stat. tit. 22, § 801(10) (2016). 
epidemiologically to create a significant risk of transmission of a communicable disease; (2) the infected person's past behavior indicates a serious and present danger that the infected person will engage in behavior that creates a significant risk of transmission of a communicable disease to another; (3) the infected person fails or refuses to cooperate with a departmental contact notification program; or (4) the infected person fails or refuses to comply with any part of either a cease and desist order or a court order issued to the infected person to prevent transmission of a communicable disease to another. [Subsection $\mathrm{C}$ omitted]. ${ }^{291}$

The most common-sense reading of the statute is that to fall within the public health threat purview, one should be an infected person, or exhibit certain behaviors of an infected person. The problem here is that Ms. Hickox was never infected with Ebola. ${ }^{292}$ The Petition asserts that

[u]pon returning to the United States, Respondent [Ms. Hickox] was detained in New Jersey by public health authorities for several days, and tested for Ebola. There is no clear evidence that tests conducted during early stages of the incubation period are accurate due to a low viral load. The test was negative. She then notified public health authorities that she intended to come to Maine. ${ }^{293}$

Though not explicitly discussed in the district court's ruling, Ms. Hickox's due process rights were at risk. In order to limit her movement, the State of Maine needed to establish that she posed an imminent threat of contagion, and that the measures it sought were necessary to protect the public's health ${ }^{294}$ and the "least restrictive measures necessary to effectively protect the public health." ${ }^{295}$ None were shown here. One can, therefore, conclude that Ms. Hickox's due process rights were vindicated in court, where public health was being used, to some extent, for political purposes.

\section{B. Statutory Remedies}

Public health statutes can be a useful tool to protect the public's health and promote its well-being. However, as Professor Gostin has noted, public health statutes are "outdated, contain multiple layers of regulation, and are inconsistent." "296 This makes it difficult to find any remedies in the health statutes

291. $I d$.

292. See Order Pending Hearing, supra note 286.

293. See Verified Petition for Public Health Order, supra note 283, at 2, ๆ 10 (emphasis added).

294. Me. Rev. Stat. tit.22, § 802(2) (2016).

295. Id. $\S 812$.

296. Lawrence O. Gostin, Public Health Law Reform, 91 Am. J. Pub. Health 1365, 1365 (2001) (noting that "public health law is often perceived as an arcane set of rules buried deep within indecipherable statute books and regulatory codes"). 
themselves. ${ }^{297}$ Nevertheless, plaintiffs can rely on non-public health statutes to vindicate their rights. One such statute is Section 1983 of the Civil Rights Act of 1871, which provides a civil action for deprivation of constitutional and federal statutory rights by persons acting under the color of law. ${ }^{298}$ For example, in 2009 , the City of El Paso, Texas passed an ordinance that prohibited food trucks from operating within 1000 feet of restaurants, grocers, and other food-service and food-product establishments. ${ }^{299}$ Plaintiffs, a group of mobile food vendors, filed a civil action against the city pursuant to the Fourteenth Amendment to the United States Constitution, the Civil Rights Act of 1871, 42 U.S.C. $\$ 1983$ and Declaratory Judgment Act, 28 U.S.C. $§ 2201 .^{300}$ The plaintiffs' complaint alleged that the restrictions passed by the city of El Paso addressed no health or safety concerns. ${ }^{301}$ Rather, they were enacted simply to protect the non-mobile businesses from their mobile competitors. ${ }^{302}$ After the lawsuit was filed, the city council repealed the law. ${ }^{303}$ Michael Hill, the director of El Paso's Department of Public Health, told the council "that [ordinance] was put in 2009 to address concerns of the fixed food establishment vendors who didn't think it would (sic) good for a mobile [vendor] to park right outside their business, but there's not a health reason or a Texas food rule that I can find that justifies that." ${ }^{304}$ The El Paso ordinance is a clear example of using public health for non-public health purposes. For plaintiffs, the ordinance proved to be a brief scare that ultimately proved to be weak manipulation of public health for non-public health purposes.

Though not used in El Paso, there are two other federal statutes that may provide limited relief. First is the Federal Torts Claims Act (FTCA), which provides for a limited waiver of sovereign immunity and allows an individual to bring a cause of action against the federal government "in the same manner and to the same extent as a private individual under like circumstances. ${ }^{305}$ But unlike 42 U.S.C. $\S 1983$, the FTCA has several hurdles for public health plaintiffs to overcome. First, plaintiff must show that the injury occurred as a result of the federal employee's negligence while acting within the scope of his

297. See id. (noting that "[e]ffective public health protection is technically and politically difficult").

298. 42 U.S.C. $§ 1983$ (2012).

299. Complaint for Declaratory and Injunctive Relief, Castaneda v. El Paso, No. 3:11-cv00035-KC (W.D. Tex. Jan 26, 2011) (on file with author).

300. Id.

301. Id.

302. Id.

303. El Paso Mobile Food Vendors Challenge City's Effort to Run Them Out of Town, Inst. FOR JUST., http://ij.org/case/el-paso-vending/ [https://perma.cc/K29P-CGNY] (last visited Mar. 31, 2017).

304. Tim Carman, In Food Truck Fights, Libertarian Law Firm Takes a Stand, WASH. PosT (Sept. 6, 2011), https://www.washingtonpost.com/lifestyle/food/in-food-truck-fights-libertarianlaw-firm-takes-a-stand/2011/08/30/gIQATNUH7J_story.html [https://perma.cc/8KWQ-SW9F].

305. 28 U.S.C. $\S 2674$ (2012). 
employment. ${ }^{306}$ Second, under the FTCA, the liability of the United States is determined "in accordance with the law of the place where the allegedly tortious act or omission occurred." ${ }^{\prime 307}$ This means that unless state law provides a remedy for that type of harm, plaintiff is not likely to prevail against the federal government. Third, before a claim is filed in federal court, the claimant must file an administrative demand against the government. ${ }^{308}$ This implicates the doctrine of issue exhaustion, an agency barrier to judicial review. ${ }^{309}$ Fourth, the FTCA includes the discretionary function exception, which bars a claim based on the exercise or performance or the failure to exercise or perform a discretionary function. ${ }^{310}$ Finally, "under the FTCA the federal government is immune from liability for misrepresentation of fact or law, whether negligent or intentional." 311 But here lies the conundrum. Most causes of action for manipulation of public health would by definition fall within misrepresentation of facts or law by government officials. As such, the FTCA forecloses one significant channel of redress for plaintiffs for illegitimate use of public health. Additionally, the FTCA prohibits punitive damages, ${ }^{312}$ therefore, it has less deterrent and retributive effects.

Second is the Alien Torts Statute ("ATS") which grants federal district courts "original jurisdiction of any civil action by an alien for a tort only, committed in violation of the law of nations or a treaty of the United States." ${ }^{.13}$ To bring a cause of action under the ATS, plaintiffs must meet three elements: (1) the claim must be made by an alien plaintiff; (2) it must be for a tort; and (3) the tort must be in violation of law of nations or treaties of United States. ${ }^{314}$ ATS claims may sometimes be brought against private actors, not only state officials, when the tortious activities violate norms of "universal concern" that are recognized to extend to the conduct of private parties, such as, slavery, genocide, and war crimes. ${ }^{315}$ Thus, on October 13, 2015, the American Civil Liberties Union filed a complaint in the federal district court for the Eastern District of Washington against the CIA contracted psychologists, James Elmer Mitchell ("Mitchell") and John Bruce Jessen ("Jessen"), who designed and ran the CIA torture program. ${ }^{316}$ The complaint, brought under the aegis of ATS alleged that "[Mitchell and

306. See Primeaux v. United States, 181 F.3d 876, 878 (9th Cir. 1999).

307. See Alvarez-Machain v. United States, 266 F.3d 1045, 1057 (9th Cir. 2001).

308. See 28 U.S.C. $\$ 2401$ (b) (2012).

309. 5 U.S.C. $\S 704$ (2012).

310. See Berkovitz v. United States, 486 U.S. 531, 535-36 (1988).

311. John Akula, Sovereign Immunity and Health Care: Can Government Be Trusted?, 19 HeALth AfF. 152, 159 (2001).

312. 28 U.S.C. $\S 2674$ (2012).

313. Id. $\S 1350$.

314. Hanoch Tel-Oren v. Libyan Arab Republic, 517 F. Supp. 542, 548 (D.D.C. 1981).

315. Abdulahi v. Pfizer, 562 F.3d 163, 173 (2nd Cir. 2009).

316. Salim v. Mitchell—Lawsuit Against Phycologists Behind CIA Torture Program, ACLU (Jan. 27, 2017), https://www.aclu.org/cases/salim-v-mitchell-lawsuit-against-psychologists-behindcia-torture-program [https://perma.cc/YP8U-99WV]. 
Jessen's] conduct constitutes [1] torture, cruel, inhumane, and degrading treatment; [2] non-consensual human experimentation; and [3] war crimes, all of which are violations of 'specific, universal, and obligatory' international law norms, as evidenced by numerous binding international treaties, declarations, and other international law instruments." 317 Although no decision has been made in the case as of the time of this writing ${ }^{318}$ one can surmise that the outcome will have major impacts not only in the intelligence arena, but for public health practice too, particularly if manipulation of public health for non-public health purposes can be framed as human rights violation. A win for the plaintiffs may open the door for foreign public health plaintiffs to seek remedies in U.S. courts under ATS. ${ }^{319}$ On the other hand, the Supreme Court has cautioned federal courts to exercise restraint in using and applying ATS. ${ }^{320}$ The Court teaches that the alien must show a violation of a well-defined norm of customary international law to prevail. ${ }^{321}$ Therefore, one can safely argue that it will be difficult for an alien plaintiff to prevail under the ATS because of the high bar set by the Supreme Court.

At the state level, State Tort Claims Acts (STCAs) are generally modeled after the FTCA. ${ }^{322}$ These STCAs either provide a general waiver of immunity

317. See Complaint and Demand for Jury Trial at 3, \4, Salim v. Mitchell, No. 2:12-civ-00286 (E.D. Wa. Oct 13, 2015), https://www.aclu.org/sites/default/files/field_document/suleiman_ complaint.pdf [https://perma.cc/PY49-6AME].

318. On April 22, 2016, District Judge Justin Quackenbush allowed the lawsuit to proceed to the discovery phase. See Nicholas K. Geranios, Judge Won't Dismiss Suit Against Spokane Psychologist over CIA Interrogation, SeAttle Times (Apr. 22, 2016), http://www.seattletimes. com/seattle-news/judge-wont-dismiss-suit-against-spokane-psychologists-over-cia-interrogation/ [https://perma.cc/GL44-YDMS].

319. See, e.g., Abdullahi v. Pfizer, Inc., 562 F.3d 163, 168 (2d Cir. 2009) (deciding case in which plaintiffs sued under ATS, claiming Pfizer had experimented on children in Nigeria without their consent). See also Decision: Re Second Amended Complaint at *1, *7, *14, Alvarez v. Johns Hopkins Univ., No. MJG-15-950, 2016 WL 7209804 (D. Md. Sept. 7, 2016) (dismissing \$1 billion lawsuit against Johns Hopkins University and others in a study where between 1946 and the mid1950s "officials of the United States Public Health Service engaged in nonconsensual medical experimentation in Guatemala and managed to conceal their actions for some sixty years," but also noting that "[t]his Court finds, as stated by the United States Court of Appeals for the Second Circuit in Abdullahi v. Pfizer, Inc.: 'Plaintiffs have pled facts sufficient to state a cause of action under the ATS for a violation of the norm of customary international law prohibiting medical experimentation on human subjects without their consent. In such an instance, ATS jurisdiction exists over plaintiffs' claims ....'”).

320. See Sosa v. Alvarez-Machain, 542 U.S. 692, 727-28 (2004) (noting that "[s]ince many attempts by federal courts to craft remedies for the violation of new norms of international law would raise risks of adverse foreign policy consequences, they should be undertaken, if at all, with great caution").

321. See id. at 728 (stating the Court is not required to define new international laws but that suits should be allowed for violations of existing international norms).

322. State Sovereign Immunity and Tort Liability, Nat'L Conf. of State Legislatures, 
with certain exceptions, ${ }^{323}$ or reenact immunity with limited waivers that apply only to certain types of claims. ${ }^{324}$ Predictably, STCAs are also plagued by the same impediments as those that plague the FTCA described above. ${ }^{325}$ Navigating the patch work of waivers of state sovereign immunities can be confusing. ${ }^{326}$ In Virginia, for example, several sections of the code extend immunity to different entities and employees. ${ }^{327}$ Additionally,

Most states divide public health functions into government or proprietary functions. There is official immunity for discretionary governmental functions but not for proprietary functions. These definitions vary greatly between states. . . Many states do not consider personal medical services such as prenatal care clinics and general indigent care clinics to be governmental functions ... although some states do include these under governmental immunity. ${ }^{328}$

For example, section 766.1115 of the Florida Access to Health Care Act provides sovereign immunity to private licensed health care providers who

http://www.ncsl.org/research/transportation/state-sovereign-immunity-and-tort-liability.aspx [https://perma.cc/B5HQ-B5SB] (last updated Sept. 8, 2010). Just like the FTCA, state public health officials have sovereign immunity when they are making policy decisions or performing discretionary functions. Edward P. Richards III \& Katharine C. Rathbun, The Legal Basis for Public Health, in Principles of Public Health Practice 59, 64 (F. Douglas Scutchfield \& C. William Keck eds., 2d ed. 2003).

323. See, e.g., FLA. STAT. $§ 768.28$ (2016) (providing waiver of immunity for some tort actions).

324. State Sovereign Immunity and Tort Liability, supra note 322.

325. See id. (listing several state acts, which include discretionary function exceptions to liability, misrepresentation exceptions to liability, and prohibitions on punitive damages against state governments).

326. See Victor E. Schwartz et Al., Prosser, Wade And Schwartz's Torts, Cases AND MATERIALS 640, 646 (10th ed. 2001) (noting that states have modeled statutes off of the FTCA but that some state laws are complex and that states vary greatly on the requirements and extent of immunity).

327. See, e.g., VA. CODE $\S 8.01-44.2$ (2016) (providing in pertinent part that "for the vaccinerelated injury or death associated with the administration of a vaccine in the Commonwealth by or under the supervision of a physician licensed to practice medicine in Virginia, no civil action shall lie against such physician, or any person administering such vaccine on behalf of such physician for injury or death resulting from an adverse reaction to such vaccine, except where such injury or death was caused by gross negligence of the physician, his agents or employees, in the administration of such vaccine"); Id. $\S 32.1-48.016$ (providing that "[a]ny person, including a person who serves in a Medical Reserve Corps (MRC) unit or on a Community Emergency Response Team (CERT), who, in good faith and in the performance of his duties, acts in compliance with this article and the Board of Health's regulations shall not be liable for any civil damages for any act or omission resulting from such actions unless such act or omission was the result of gross negligence or willful misconduct").

328. Richards \& Rathbun, supra note 322, at 65. 
deliver health care services to low-income residents of Florida with incomes at or below $200 \%$ of the Federal Poverty Level. ${ }^{329}$ On the other hand, a corporation providing medical care to inmates in a county jail is not "primarily acting as an instrumentality or agency of the state or its subdivisions" to qualify for sovereign immunity. ${ }^{330}$ In one case, the defendant, a corporation, entered into a contract with the Sheriff to provide medical services to inmates of the Hillsborough County Jail. ${ }^{331}$ The defendant then contracted with a physician to provide those services and to serve as the jail's medical director. ${ }^{332}$ The plaintiff, an inmate of the jail, was later examined and treated by the physician. ${ }^{333}$ The plaintiff claimed that due to the physician's negligent actions, the plaintiff developed a vascular disease which led to partial amputation of his right leg. ${ }^{334}$ The defendant argued sovereign immunity as an agency of the state. ${ }^{335}$ However, the court found that because the corporation was an independent contractor, the parties had clearly defined their relationship in a way that denied the defendant was "a corporation primarily acting as an instrumentality or agency of the state or its subdivisions." 336

In sum, many statutory sovereign immunity cases involve individuals injured in medical malpractice, or a government employee committing a tort while acting within the scope of his employment. The FTCA and STCAs provide limited waivers for plaintiffs. For individuals injured outside the country (i.e., aliens), the ATS may provide them with subject matter jurisdiction in federal courts. ${ }^{337}$ Critics may contend, with some force, that these types of causes of action (FTCA, ATS, and STCAs) differ markedly from the central thesis of this Article, which is remedy for harm suffered as a result of manipulation of public health for nonpublic health purposes, acts that are mostly done by politicians and policy makers. I concede that for those types of harm the abovementioned statutes provide little, if any, relief. However, some manipulation of public health is done by government officials, in which case this Article suggests FTCA, ATS, and STCAs as some possible remedies, despite their limitations. Additionally, this Article suggests that despite the U.S. Constitution's Article III standing requirements (such as prohibition on generalized grievances), ${ }^{338}$ Congress could certainly create statutes that recognize manipulation of public health as one of the injuries it seeks to protect against. In the absence of that, common law remedies may provide better alternatives.

329. Fla. STAT. § 766.1115 (2016).

330. Mingo v. ARA Health Serv., Inc., 638 So. 2d 85, 86 (Fla. Dist. Ct. App. 1994).

331. Id. at 85 .

332. Id. at 86 .

333. Id.

334. Id.

335. Id.

336. $I d$.

337. 28 U.S.C. $\S 1350$ (2012).

338. U.S. ConST. art. III, § 2, cl. 1; see Hessick, supra note 263, at 296 (discussing that generalized grievances alone do not create standing). 


\section{Common Law Remedies}

Common law may provide some form of remedy for those negatively impacted by misuse of public health. One commentator has noted that "[s]o far as it relates to the public health, the principles of the common law may be summed up in the maxim, sic utere tuo ut alienum non laedas ${ }^{339}$ but the remedy which it provides usually comes too late, since the injury has been inflicted, and pecuniary damages cannot compensate for ruined health and lost lives." 340 Conceivably, injury to property may be analogous to injury to health, particularly concerning the environment or public nuisance. ${ }^{341}$ Although the discussion that animates this Article goes beyond the use of property causing injury to another, it suggests that plaintiffs can draw from the tort doctrines of informed consent and public nuisance, and to some extent environmental law, to inform their remedies.

1. Informed Consent.- - The concept of informed consent is well established in the field of bioethics, but its application is unclear in the area of public health. ${ }^{\prime 342}$ Whereas informed consent works better where there are individual choices, the health of the population in general cannot be conditioned on whether the group is informed. ${ }^{343}$ "For example, road safety, food safety, water safety, safe medicines and measures that protect against infection [including vaccinations] cannot be tailored to individual choice. ${ }^{344}$ However, informed consent and public health are not necessarily incompatible. ${ }^{345}$ In illuminating this point, Professor Wendy Parmet notes that "informed consent advances four major goals: compensation of injuries, prevention of injuries, promotion of trust, and recognition of choice." ${ }^{346}$ It is the first goal of informed consent-compensation of injuries - that this Article addresses.

339. Sic utere tuo ut alienum non laedas means "use your own property in such a way that you do not injure other people's." Overview: Sic utere tuo ut alienum non laedas, OXFORD REFERENCE, http://www.oxfordreference.com/view/10.1093/oi/authority.20110803100504563 [https://perma.cc/J7U6-6K3D] (last visited Mar. 31, 2017). "The principle that one should use his own property in such a way that he does not injure that of another is to be found early in the common law." Elmer E. Smead, Sic Utere Tuo Ut Alienum Non Laedas: A Basis of the State Police Power, 21 CoRnell L. Q. Rev. 276, 276 (1936).

340. John S. Billings, Introduction: Jurisprudence of Disease, in 1 A TREATISE ON HygIENE AND Public Health 3, 40 (Albert H. Buck ed., 1879).

341. See id. at 39-40 (comparing the principle of nuisance in property law to nuisance caused by health concerns).

342. Jessica Wilen Berg, All for One and One for All: Informed Consent and Public Health, 50 Houston L. Rev. 1, 1 (2012).

343. Onora Oneil, Informed Consent and Public Health, 359 Phil. Transactions of the ROYAL SOC'Y OF LONDON B 1133, 1135 (2004).

344. Id.

345. Wendy E. Parmet, Informed Consent and Public Health: Are They Compatible When It Comes to Vaccines, 8 J. Health Care L. \& Pol'y 71, 73 (2005).

346. Id. 
Traditional public health informed consent litigation has often involved medical research where researchers fail to adequately inform the subjects of the risks involved or carry out the research in ways considered unethical. ${ }^{347}$ Although it is hard to fathom how one can be informed about the misuse of public health, victims have in the past claimed that they were either misled or that pertinent public health information was withheld from them. ${ }^{348}$ For example, in Madrigal v. Quilligan, between 1971 and 1974, in Los Angeles County General Hospital in California, several Mexican-American women were involuntarily sterilized after giving birth as part of a federally funded program aimed at population control. $^{349}$ The pro-sterilization arguments were predicated on the protection of the public's health and resources. ${ }^{350}$ As a result, ten women filed a class action lawsuit against the county hospital, alleging among other things,

that their civil and constitutional rights to bear children had been violated, and that between 1971 and 1974 they had been victims of unwanted operations: coerced into signing consent forms hours or minutes before or after labor, not told that the procedure was irreversible, or simply sterilized without giving any consent. ${ }^{351}$ The plaintiffs lost the case in the lower court, ${ }^{352}$ and the Ninth Circuit later affirmed without an opinion. ${ }^{353}$

Despite the Madrigal plaintiffs' loss, the fact that they were able to allege lack of informed consent where public health was used illegitimately ${ }^{354}$ indicates that it can be a plausible remedy. For example, in 1989, members of the Havasupai, a Native American tribe in Arizona, asked an Arizona State University (ASU) professor to investigate the high rates of diabetes occurring in the tribe. ${ }^{355}$ The researchers drew blood samples from several tribal members ostensibly for the study of diabetes. ${ }^{356}$ Years later, "Although the project ended for the purposes allegedly consented to by the Havasupai, researchers at ASU and elsewhere, including the University of Arizona, continued to perform research

347. See, e.g., Amy Harmon, Indian Tribe Wins Fight to Limit Research on its DNA, N.Y. TiMES (Apr. 21, 2010), http://www.nytimes.com/2010/04/22/us/22dna.html?pagewanted=all [https://perma.cc/GD3E-W3DF].

348. See, e.g., Madrigal v. Quilligan, 639 F.2d 789 (9th Cir. 1978); Harmon, supra note 347.

349. Alexandra Minna Stern, Sterilized in the Name of Public Health: Race, Immigration, and Reproductive Control in Modern California, 95 Am. J. Pub. Health 1128, 1128 (2005).

350. Id. at 1135.

351. Id. at 1134 .

352. Id. at 1135 .

353. Madrigal, 639 F.2d at 789.

354. Stern, supra note 349 , at 1135.

355. Havasupai Tribe of the Havasupai Reservation v. Ariz. Bd. of Regents 204 P.3d 1063, 1066 (Ariz. Ct. App. 2009).

356. Katherine Drabiak-Syed, Lessons from Havasupai Tribe v. Arizona State University Board of Regents: Recognizing Group, Cultural, and Dignitary Harms as Legitimate Risks Warranting Integration into Research Practice, 6 J. HEALTH \& BiOMEDICAL L. 175, 181 (2010). 
and publish articles based on data from tribal members' blood samples." ${ }^{\prime 37}$ In 2004, the tribe sued Arizona State University and Arizona Board of Regents, alleging among other things that "ASU conducted genetic research using tribal members' blood samples, published papers that disclosed tribal members' private genetic data and other private information derived from the blood samples, and transferred blood samples to third parties without consent." ${ }^{358}$ After several years of litigation, the case was settled for $\$ 700,000$ in $2010 . .^{359}$ Because the case settled, no legal precedent was formed. However, the litigation may stand for the principle that " $[\mathrm{w}]$ hen individuals donate human biological materials to an institution for research purposes, an un-consented use of the donors' samples may constitute grounds for a cause of action against the research institution and the researchers themselves." ${ }^{360}$ Put succinctly, misuse of public health has consequences.

2. Public Nuisance.-The Restatement (Second) of Torts defines a public nuisance as "an unreasonable interference with a right common to the general public." 361 According to the Restatement,

Circumstances that may sustain a holding that an interference with a public right is unreasonable include the following: (a) Whether the conduct involves a significant interference with the public health, the public safety, the public peace, the public comfort or the public convenience, or (b) whether the conduct is proscribed by a statute, ordinance or administrative regulation, or (c) whether the conduct is of a continuing nature or has produced a permanent or long-lasting effect, and, as the actor knows or has reason to know, has a significant effect upon the public right. ${ }^{362}$

The first factor, "whether the conduct involves a significant interference with the public health, the public safety, the public peace, the public comfort or the public convenience," $" 363$ is in tandem with this discussion. Generally, "Health nuisance examples include public health threats such as breeding areas for flies, collection of sewage, water serving as a mosquito breeding areas, rat harborages, bed bugs and other mediums of disease transmission." ${ }^{364}$ But none of these are fundamentally caused by misuse of public health for non-public health purposes. One notable exception to the list and controversial application of the public

357. Havasupai Tribe, 204 P.3d at 1067.

358. Id. at 1074 .

359. Harmon, supra note 347.

360. Drabiak-Syed, supra note 356, at 185.

361. Restatement (SeCOND) OF Torts $\S 821 B$ (Am. LAw InSt. 1979).

362. Id.

363. Id

364. Kathleen Hoke, Partnership for Public Health Law Advancing Public Health Through Law: Overview of Nuisance Law, AM. PuB. HeALTH Ass'N, https://www.apha.org/ /media/files/ pdf/factsheets/overview_of_nuisance_law_factsheet.ashx [https://perma.cc/8WSH-3Y7J] (last visited Mar. 31, 2017) 
nuisance doctrine was the closing of gay bath houses in New York City and San Francisco during the HIV/AIDS epidemic. ${ }^{365}$ In 1985, the State Public Health Council added a new regulation to the state sanitary code that expressly authorized local officials to close any facilities "in which high risk sexual activity takes place." ${ }^{366}$ Such facilities were deemed to "constitute a public nuisance dangerous to the public health." ${ }^{367}$ New York City then sought an injunction to close one commercial establishment, St. Mark's Baths, claiming it was a public nuisance because the health risks at St. Mark's met the criteria for prohibited facilities laid out in the state regulation. ${ }^{368}$ St. Mark's opposed the injunction, arguing among others that the ordinance was impermissibly vague, that it was not responsible for the sexual activities of third parties, and that the city had no discretion to pursue the remedy of injunctive relief. ${ }^{369}$ The court denied St. Mark's arguments and issued a preliminary injunction on behalf of the city. ${ }^{370}$

The question from this case is whether the closing of the bath house was a bona fide public health decision, or, as this Article posits, use of public health for non-public health purposes. There is a general discussion that these closures were mostly geared toward regulating unpopular sexual behaviors, specifically that of gays and lesbians, ${ }^{371}$ than toward disease control. One commentator has noted that

[1]ooking into the AIDS abyss in the mid-1980s, public health officials sometimes succumbed to the same impulses-notably, panic and scapegoating - that activated politicians, judges, and the public itself. Among the best-known results of these impulses were city-by-city efforts to shut down gay bathhouses. No one disputed that sexual activity went on in the bathhouses, but it was-and remains-unclear whether closing them would help stop the transmission of HIV, hinder that effort, or have no net effect. ${ }^{372}$

The New York court acknowledged this point, and then rejected it by noting as follows:

To be sure, defendants and the intervening patrons challenge the

365. See Yishai Blank \& Issi Rosen-Zvi, The Geography of Sexuality, 90 N.C.L. Rev. 955 , 988-89 (2012) (noting the closing of one New York City bath house and of virtually all gay bath houses in San Francisco as a means to regulate "sexually oriented businesses").

366. New York v. New Saint Mark’s Baths, 497 N.Y.S.2d 979, 981 (N.Y. Sup. Ct. 1986).

367. Id.

368. Id.

369. Id. at 984 .

370. Id.

371. See Blank \& Rosen-Zvi, supra note 365, at 1010 (suggesting that city governments sometimes use their public health, zoning, or licensing powers to target and exclude gay establishments). The authors also noted that "due to the prevalent belief that gay sex is riskier for transmitting sexually transmitted diseases, gay establishments are exposed to a higher risk of being declared a public nuisance." Id. at 990.

372. John G. Culhane, Sex, Fear, and Public Health Policy: Gay Bathhouses and Public Health Policy, 5 Yale L.J. Health Pol'y L. \& Ethics 327, 327 (2005). 
soundness of the scientific judgments upon which the Health Council regulation is based, citing, inter alia, the observation of the City's former Commissioner of Health in a memorandum dated October 22, 1985 that "closure of bathhouses will contribute little if anything to the control of AIDS." . . . Defendants particularly assail the regulation's inclusion of fellatio as a high risk sexual activity, and argue that enforced use of prophylactic sheaths would be a more appropriate regulatory response. They go further and argue that facilities such as St. Marks, which attempts to educate its patrons with written materials, signed pledges, and posted notices as to the advisability of safe sexual practices, provide a positive force in combatting AIDS, and a valuable communication link between public health authorities and the homosexual community. While these arguments and proposals may have varying degrees of merit, they overlook a fundamental principle of applicable law: "It is not for the courts to determine which scientific view is correct in ruling upon whether the police power has been properly exercised. The judicial function is exhausted with the discovery that the relation between means and end is not wholly vain and fanciful, an illusory pretense." ${ }^{373}$

The decision aside, an important point in this case is that the injunctive remedy was sought by the city and not private plaintiffs. ${ }^{374}$ Traditionally, courts have allowed only public entities to bring public nuisance claims, and have allowed only injunctive, rather than legal remedies ${ }^{375}$ More recently, however, private parties have been permitted to maintain public nuisance claims if they can show that they have undergone a "special injury" that is unique from a general injury to the public. ${ }^{376}$ For example, Georgia provides a private right of action for a public nuisance if an individual suffers "special damage." ${ }^{377}$ Whether injuries emanating from the manipulation of public health can be sustained on a public nuisance theory as special damages is hard to tell. The message here is that where possible, plaintiffs should try to use nuisance theory in their complaints. For example, public health plaintiffs can request injunctive reliefs from courts to require the defendant to cease his activity. Injunctive reliefs are ordinarily allowed against both ongoing and imminent harms. ${ }^{378}$

373. New York v. New Saint Mark's Baths, 497 N.Y.S.2d 979, 983 (N.Y. Sup. Ct. 1986) (quoting Chiropractic Ass'n of N.Y. v. Hilleboe, 12 N.Y.2d 109, 114 (N.Y. 1962)).

374. See generally id.

375. George P. Smith II \& Gregory P. Bailey, Regulating Morality Through the Common Law and Exclusionary Zoning, 60 CATH. U. L. REV. 403, 420 (2011).

376. Id.

377. GA. CoDE ANN. $§ 41-1-3$ (2016) (providing that "[a] public nuisance generally gives no right of action to any individual. However, if a public nuisance in which the public does not participate causes special damage to an individual, such special damage shall give a right of action").

378. Richard A. Epstein, Cases and Materials on Torts 707 (9th ed. 2008). 


\section{Environmental Law}

Closely related to public and private nuisance is the field of environmental law which "stands for all legal rules that are aimed at the protection and development of the environment and its compartments as well as the protection of public health from harm, risks, and nuisances arising from the environment and the human-made interaction with the environment." ${ }^{379}$ Traditionally, environmental law has been concerned with preventing pollution. ${ }^{380}$ Thus, federal statutes such as the Clean Air Act, ${ }^{381}$ the Clean Water Act ${ }^{382}$ Safe Drinking Water Act, ${ }^{383}$ and the Comprehensive and Environmental Response, Compensation and Liability $\mathrm{Act}^{384}$ are designed to curb pollution. However, there has been a movement to expand environmental law to cover not only the effects of pollution on the environment, but to health injuries suffered by individuals. ${ }^{385}$ Thus, environmental crimes might involve cases with both significant environmental impacts and public health effects, though many cases with public health effects may have only negligible environmental consequences. ${ }^{386}$ The question then arises: Can individuals injured by misuse of public health rely on environmental law as a source of remedy? It would seem that the answer would be a qualified yes. This might occur, for example, where a public health or environmental law with marginal public health benefits requires an individual or business to undergo great expense and inconvenience to comply with it, ${ }^{387}$ as shown by some of the local ordinances regulating food truck vendors. ${ }^{388}$ Alternatively, the

379. Adem Koyuncu, Environmental Law and Public Health, in ENCYClOPEDIA OF PubliC Health 334, 334 (Wilhelm Kirch ed., 2008).

380. See Victoria Sutton, Environment and Public Health in a Time of Plague, 30 Am. J.L. \& MED. 215, 222 (2004) (noting that " $[t]$ he triggering event for a movement in federalism occurred for federal environmental law in 1970 with the culmination of public demand for the federal government to address the growing problem of environmental pollution"); David M. Uhlmann, Environmental Law, Public Health and the Values Conundrum, 3 Mich. J. EnvtL. \& Admin. L. 231, 234 (2014) (noting that "[o]ur environmental laws focus on the need for pollution prevention to protect public health").

381. 42 U.S.C. $\$ \S 7401-7671 q(2012)$.

382. 33 U.S.C. $\S \S 1251-1388$ (2012).

383. 42 U.S.C. $\S \S 300 f-300 j-25$ (2012).

384. Id. $\S \S 9601-9675$.

385. See Uhlmann, supra note 380 , at 232-33 (discussing several cases involving environmental crimes that resulted in injuries or death).

386. Id. at 233.

387. Christopher Reynolds, Public and Environmental Health Law: Statutory Powers, Procedural Fairness and Legal Liability 129 (2011).

388. See Ernesto Hernandez-Lopez, The Global Politics of Food: Sustainability and Subordination: LA's Taco Truck War: How Law Cooks Food Culture Contests, 43 U. MiAmi InTERAM. L. REv. 233, 251 (2011) (noting that "[w]hen the Board of Supervisors for the County passed the [food truck] Ordinance in April of 2008, local and national media quickly commented on the public and gastronomic controversy of effectively banning taco trucks in East L.A., an area identified with Mexican culture and taco trucks"). 
environmental law itself may provide remedies within its structure. For example, in Tavitian v. Public Health and Environmental Health Council, ${ }^{389}$ the City of Playford in South Australia had determined that Tavitian's premises were unsanitary and issued a notice that required him to take specific actions to improve his property's condition, pursuant to the Public Environmental Health Act of $1987 .{ }^{390}$ Tavitian had accumulated "numerous items and objects including garden waste, iron, timber, plastic, tyres, dilapidated motor vehicle bodies containing refuse and rubbish, motor parts, mattresses and a variety of metal frames [and] tubing." ${ }^{391}$

In challenging the notice, Tavitian argued, among other things, that he was "denied natural justice by the Council in that he was not given a chance to be heard nor an opportunity to cross examine witnesses", ${ }^{392}$ that "[t]he finding that there was a rodent infestation [on his premises] was made by inference rather than the evidence of the witnesses"; and that "[t]he evidence before the Committee was not sufficient to establish an insanitary condition." ${ }^{\prime 393}$ In finding for the City, the district court noted, "Under the Act, it is the duty of a local council . . to take reasonable steps to prevent any infestation or spread of vermin, rodents or other pests within its council area." ${ }^{\$ 394}$ More importantly, the Act provides that the recipient of a notice is required to take the action prescribed in the notice, but may appeal to the council's review committee. ${ }^{395}$ Furthermore, once the review committee has made a determination, the recipient may appeal against that determination to the Administrative and Disciplinary Division of the District Court, ${ }^{396}$ and finally to the Supreme Court. ${ }^{397}$ Thus, an environmental law that provides public health remedies within its structure ensures enforcement provisions that are likely to protect plaintiffs. ${ }^{398}$ No party has ever brought a formal case seeking remedies, based on the environmental provisions of any state or federal statute, as a result of the manipulation of public health for non-public health purposes. But recent events may prove prescient. In November 2011, Michigan Governor Rick Snyder declared a financial emergency in the city of Flint due to the city's mounting debt, and appointed an emergency manager to

389. [2008] SADC 118 (Austl.), https://jade.io/article/83863 [https://perma.cc/WJ4M-DQQ5].

390. Id. ๆ1.

391. Michele Slatter, Law and Mess, in SeVere Domestic SQuAlor 123, 131 (John Snowdon et al. eds., 2012).

392. Tavitian, [2008] SADC 118, $₫ 18$.

393. Tavitian v Pub \& Envtl Health Council (No. 2) [2009] SADC 29, I 5 (Austl.), https://jade.io/article/91619 [https://perma.cc/GG3Q-RNKR].

394. Tavitian, [2008] SADC 118, ๆ 7.

395. Id. ๆ2.

396. Id. $₫ 3$.

397. See Tavitian, [2009] SADC 29, $\uparrow 7$ (noting the case could be taken to the Supreme Court if Tavitian wanted to further appeal his case).

398. For example, the Safe Drinking Water Act (SDWA) creates a civil cause of action against any person, including a governmental instrumentality, alleged to be in violation of any requirement prescribed by or under the Act. 42 U.S.C. $\S 300 j-8(a)(1)(2012)$. 
take over the city's operations. ${ }^{399}$ In 2014 , the city began using water from the Flint River instead of Lake Huron solely to save money. ${ }^{400}$

Until April 2014, the Flint River had not been used as a primary source of drinking water for city residents for over fifty years. This was largely due to the number of health threats in the Flint River, including but not limited to improperly disposed of chemicals; animal wastes; pesticides; human wastes; wastes injected deep underground; and naturallyoccurring substances affecting surface water. ${ }^{401}$

Around the time that the city began taking water from the river, it also stopped implementing the corrosion-control treatments required by the Environmental Protection Agency's Lead and Copper Rule. ${ }^{402}$ The city added ferric chloride to reduce the formation of trihalomethanes, ${ }^{403}$ water treatment byproducts that pose health risks and are regulated by the Environmental Protection Agency. ${ }^{404}$ The ferric chloride increased the corrosivity of the river water. ${ }^{405}$ "The water reaching consumers was therefore 19 times as corrosive as it had been when the source was Lake Huron. The more corrosive water is, the more readily it can dissolve metals such as lead. ${ }^{\$ 406}$ Several lawsuits were filed against the city, the City Administrator, the Michigan Secretary of Treasury, and the Michigan Governor, among others. ${ }^{407}$ The lawsuits alleged several causes of action including violations of the Safe Drinking Water Act, ${ }^{408}$ Due Process

399. Complaint for Declaratory and Injunctive Relief at *2, Concerned Pastors for Soc. Action v. Khouri, No. 16-10277, 2016 WL 319206 (E.D. Mich. Jan. 27, 2016).

400. David C. Bellinger, Lead Contamination in Flint-An Abject Failure to Protect Public Health, 374 New EnG. J. Med. 1101, 1101 (2016).

401. Plaintiff's Brief in Opposition to Defendant's City of Flint and City of Flint City Administrator Natasha Henderson's Motion to Dismiss Pursuant to Fed. R. Civ. P. 12(b)(1) and (6), Coalition for Clean Water v. Flint, No. 2:15-cv-12084-SJM-DRG, 2015 WL 4549921 (E.D. Mich. filed July 7, 2015).

402. Bellinger, supra note 400. See 40 C.F.R. $\S 141.82(\mathrm{~g})$ for the Lead and Copper Rule.

403. Id.

404. Renee Sharp \& J. Paul Pestano, Water Treatment Contaminants: Forgotten Toxins in American Water, EWG (Feb. 27, 2013), http:/www.ewg.org/research/water-treatmentcontaminants [https://perma.cc/J6LF-QZ2S].

405. Bellinger, supra note 400.

406. Id. at 1101-02.

407. See, e.g., Complaint and Demand for Jury Trial, Collins v. Snyder, No. 16106077-CZ, 2016 WL 183880 (Mich. Cir. Ct. filed Jan. 7, 2016); Complaint for Declaratory and Injunctive Relief, Concerned Pastors for Soc. Action v. Khouri, No. 16-10277, 2016 WL 319206 (E.D. Mich. filed Jan. 27, 2016); Complaint for Injunctive and Declaratory Relief Money Damages and Jury Demand, Mays v. Snyder, No. 2:15-cv-14002-JCO-MKM, 2015 WL 7175656 (E.D. Mich. filed Nov. 13, 2015); Complaint for Injunctive Relief, Declaratory Relief and Violation of Plaintiffs Fourteenth Amendment Right to Due Process, Coalition for Clean Water v. Flint, No. 15-104900CZ, 2015 WL 4997110 (Mich. Cir. Ct. June 9, 2015).

408. See Complaint for Declaratory and Injunctive Relief $19169,171,173,175$, Concerned 
Clause, ${ }^{409}$ and Equal Protection Clause. ${ }^{410}$ Additionally, the cases alleged that residents had been voicing concerns about their drinking water for almost two years. ${ }^{411}$ Government officials, however, maintained that the water was safe to drink, dismissing citizens' concerns and even disregarding research findings that revealed dangerously high levels of lead in the water. ${ }^{412}$ If true, this would be an example of misusing public health to save money, and, arguably, manipulating public health for non-public health purposes. ${ }^{413}$

"The dramatic reduction over the past 40 years in blood lead levels in the U.S. population is rightly regarded as one of the cardinal public health success stories." ${ }^{414}$ What happened in Flint, Michigan, can only be described as "an abject failure to protect public health." 415 If the plaintiffs prevail on any grounds of violation of the Safe Drinking Water Act, then environmental law will be shown to be a powerful public health remedy as well.

\section{CONCLUSION}

Public health has often been used to subvert the very same goals it is designed to achieve. The results can be - and often are-harmful to the practice. This Article takes up three recent examples-anti-abortion legislation, the Affordable Care Act legislation, and the 2014 Ebola Virus Disease (EVD) outbreak and response- to illuminate how public health aims have been compromised or misused through political and legislative rhetoric. The Article avers that the non-public health purposes should warrant a more inhospitable reception within the public health community in general and courts in particular. To be sure, "[t]he use of motivated reasoning to justify political positions and the rejection of scientific evidence and data are not new nor unique to" public

Pastors for Soc. Action, 2016 WL 319206 (alleging several separate violations of the Act).

409. Complaint for Injunctive Relief, Declaratory Relief and Violation of Plaintiffs Fourteenth Amendment Right to Due Process, Coalition for Clean Water v. Flint, 2015 WL 4997110; see also Complaint for Injunctive and Declaratory Relief Money Damages and Jury Demand 9 2, Mays. 2015 WL 7175656 (alleging violation of the Due Process Clause of the Fourteenth Amendment).

410. Complaint for Injunctive and Declaratory Relief Money Damages and Jury Demand 96 , Mays, 2015 WL 7175656 (alleging violation of the Due Process Clause of the Fourteenth Amendment).

411. Complaint for Declaratory and Injunctive Relief 9 7, Concerned Pastors for Soc. Action, 2016 WL 319206.

412. Id.

413. On April 20, 2016, two Michigan environmental regulators were criminally charged with, "allegedly misleading federal environmental officials and tampering with evidence related to lead testing of Flint's water. [One regulator] faces an additional felony count for authorizing the operation of the Flint water-treatment plant when he allegedly knew it couldn't provide safe drinking water." Kris Maher, Three Officials Criminally Charged Over Flint Water Crisis, WALL STREET J. (Apr. 20, 2016), http://www.wsj.com/articles/three-officials-to-face-criminal-chargesover-flint-water-crisis-1461166410 [https://perma.cc/BJ7W-U9GZ].

414. Bellinger, supra note 400.

415. Id. 
health. ${ }^{416}$ Nevertheless, the misuse of public health by legislators coupled with "the absence of a public health voice in many policy debates has been an impediment to both a general understanding of public health remedies and acceptance by the public at large and policymakers. ${ }^{" 417}$ To this end, the Article suggests potential remedies for victims of misuse of public health for non-public health purposes, to wit, the Fifth and Fourteenth Amendments' Due Process and Equal Protection Clauses, and statutory and common law remedies.

416. Paul Diehl, Texas Politicians Should Stop Crafting Solutions to Problems That Don't Exist, DALL. News (Aug. 2, 2016), http://www.dallasnews.com/opinion/latest-columns/20160802paul-diehl-texas-politicians-should-stop-crafting-solutions-to-problems-that-don-t-exist.ece [https://perma.cc/Q3T8-WXJN].

417. Peter D. Jacobson \& Soheil Soliman, Legal and Human Rights Intervention for Health: Co-opting the Health and Human Rights Movement, 30 J. L. MED. \& ETHICs 705, 712 (Winter 2002). 